\title{
Temperature sensitivity of soil organic carbon respiration along the Rwenzori montane forests elevational transect in Uganda
}

Joseph Okello ${ }^{1,2,3,4}$, Marijn Bauters ${ }^{1,2}$, Hans Verbeeck $^{2}$, Samuel Bodé ${ }^{1}$, John Kasenene ${ }^{3}$, Astrid Françoys ${ }^{1,5,6}$, Till Engelhardt ${ }^{7}$, Klaus Butterbach-Bahl ${ }^{8}$, Ralf Kiese ${ }^{8}$ and Pascal Boeckx ${ }^{1}$

$5 \quad{ }^{1}$ Isotope Bioscience Laboratory - ISOFYS, Ghent University, Coupure Links 653, 9000 Gent, Belgium

${ }^{2}$ CAVElab- Computational and Applied Vegetation Ecology, Ghent University, Coupure Links 653, 9000 Gent, Belgium ${ }^{3}$ School of Agriculture and Environmental Sciences, Mountains of the Moon University, P.O Box 837, Fort Portal, Uganda ${ }^{4}$ National Agricultural Research Organisation, Mbarara Zonal Agricultural Research and Development Institute, P.O Box 389, Mbarara, Uganda

$10 \quad{ }^{5}$ Soil Fertility and Nutrient Management (SoFer), Ghent University, Coupure Links 653, 9000 Gent, Belgium ${ }^{6}$ Soil Physics (SoPHy), Ghent University, Coupure Links 653, 9000 Gent, Belgium.

${ }^{7}$ Sweco, Arenbergstraat 13, 1000 Brussels, Belgium

${ }^{8}$ Institute for Meteorology and Climate Research, Atmospheric Environmental Research (IMK-IFU), Karlsruhe Institute of Technology, Kreuzeckbahnstrasse 19, Garmisch-Partenkirchen 82467, Germany

15 Correspondence to: Joseph.Okello@UGent.be

Key words: Temperature sensitivity, $\mathrm{CO}_{2}$ respiration, climate warming, Afromontane forests 
https://doi.org/10.5194/bg-2022-37

Preprint. Discussion started: 8 February 2022

(c) Author(s) 2022. CC BY 4.0 License.

(c) (i)

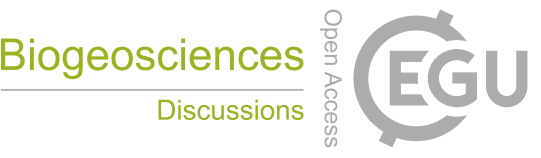

\section{Abstract}

Tropical montane forest store high amounts of soil organic carbon. However, global warming may affect these carbon stocks

20 by enhancing soil organic carbon respiration. Better insight into temperature response of soil organic carbon respiration can be obtained from in and ex situ warming studies. In situ warming via translocation of intact soil mesocosms was carried out along an elevational transect ranging between ca. $1250 \mathrm{~m}$ a.s.l. in the Kibale Forest to ca. $3000 \mathrm{~m}$ a.s.l. in the Rwenzori Mountains. Samples from the same transect were also warmed ex situ to determine temperature sensitivity. The ex situ results revealed that along the natural climate gradient in the elevational transect, specific heterotrophic $\mathrm{CO}_{2}$ respiration

25 decreased linearly by $1.01 \pm 0.12 \mu \mathrm{g} \mathrm{C} \mathrm{h}^{-1} \mathrm{~g}^{-1}$ SOC per $100 \mathrm{~m}$ of elevation increase. Similarly, the temperature sensitivity increased from $1.50 \pm 0.13$ in the lowest elevation clusters to $2.68 \pm 0.25$ in the highest elevation cluster, showing a linear decrease of $0.09 \pm 0.03$ per $100 \mathrm{~m}$ of elevation increase. Additionally, the ${ }^{13} \mathrm{C}$ depletion factor of the respired $\mathrm{CO}_{2}$ decreased linearly by $0.23 \pm 0.04 \%$ per $100 \mathrm{~m}$ of elevation increase. The results indicate an increased recalcitrance and decreased mineralisation of soil organic carbon with elevation driven by decreasing soil temperature and $\mathrm{pH}$. Subsequently, after two

30 years of in situ warming $\left(0.9\right.$ to $\left.2.8{ }^{\circ} \mathrm{C}\right)$, specific heterotrophic soil organic carbon respiration tends to be lower for warmed as compared to control soil. Further, in warmed soils, ${ }^{13} \mathrm{C}$ and content of soil organic carbon relatively increased and decreased, respectively. This indicates increased mineralisation and depletion of readily available carbon during two years of warming. In conclusion, our results suggest that climate warming may trigger enhanced losses of soil organic carbon from tropical montane forests, due to a combination of a higher temperature sensitivity of mineralisation and soil organic carbon content. 
https://doi.org/10.5194/bg-2022-37

Preprint. Discussion started: 8 February 2022

(c) Author(s) 2022. CC BY 4.0 License.

(c) (i)

\section{Introduction}

Tropical forests store $55 \%$ of the global forest carbon (C) stocks of which $56 \%$ is stored in biomass, $32 \%$ in soil and $12 \%$ in litter and deadwood (Pan et al., 2011). These forests account for more than one-third of primary productivity (Beer et al., 2010; Pan et al., 2011), despite covering only less than $10 \%$ of the global land area (Cuni Sanchez et al., 2021; Erb et al.,

40 2018). Their key role in the global $\mathrm{C}$ cycle is further demonstrated by the fact that tropical forests exchange more carbon dioxide $\left(\mathrm{CO}_{2}\right)$ with the atmosphere than any other ecosystem (Friedlingstein et al., 2020; Lewis et al., 2015; Singh, 2018), in part owing to their high $\mathrm{C}$ turnover rates (Sayer et al., 2011). Currently, tropical ecosystems are being subjected to global change, with detrimental consequences for its ecosystem services (Gütlein et al., 2018). The global temperature increase is being driven by global climate warming and local land use change (Friedlingstein et al., 2020; Zhang et al., 2005; Ipcc,

45 2018). For instance, worldwide, the average surface temperature has been rising consistently by between $0.95-1.20{ }^{\circ} \mathrm{C}$ from 1850 to 2020 (Ipcc, 2021). In addition to the global climate warming effect, the tropical forests are also experiencing local and regional temperature increases driven by land use change, which alters the fluxes of solar and thermal infrared radiation, sensible, and latent heat and ultimately changes the surface albedo (Mahmood et al., 2014; Zeng et al., 2021). As an example, between the year 2000 and 2014, agricultural expansion at the expense of montane forests caused a general

50 increase in air temperature of $0.05 \pm 0.01{ }^{\circ} \mathrm{C}$ in the Albertine rift mountains of Africa, and air warming of up to $2{ }^{\circ} \mathrm{C}$ can occur under extensive deforestation (Zeng et al., 2021). The increase in global and regional temperature has the potential to drastically alter the C cycle in tropical forests (Mohan, 2019; Nottingham et al., 2020; Sayer et al., 2019), and may potentially drive accelerated soil organic C losses (Friedlingstein et al., 2020; Kim et al., 2016). However, the response of tropical forest soils to such temperature increases is largely uncertain, especially in mountainous areas (Nottingham et al.,

55 2020; Sayer et al., 2019; Zeng et al., 2021), and generally data on climate warming from tropical forests in Africa are hardly available.

Key in this ecosystem-level uncertainty, is the specific effect of warming on soil respiration rates (Carey et al., 2016; Crowther et al., 2016; Fussmann et al., 2014). Indeed, up to about $40 \%$ of the $\mathrm{CO}_{2}$ emissions from tropical forest ecosystems

60 originate from soil respiration (both autotrophic and heterotrophic respiration) (Malhi, 2012), of which approximately $60 \%$ of the $\mathrm{CO}_{2}$ respiration from soil is derived from heterotrophic microbial activity during the mineralisation of organic $\mathrm{C}$ (Sayer and Tanner, 2010). Temperature increases in tropical forests can trigger accelerated respiration rates, yet the ecosystems' net primary productivity is already close to its maximum, thereby reducing the net C sink (Carey et al., 2016; Craine et al., 2010; Nottingham et al., 2020). Therefore, given the sheer magnitude of both the C storage and emission

65 capacities of tropical forest soils, precise quantifications and assessment of their response to climate warming are needed to inspire climate-sensitive forest management and to improve parameterisation and predictions of earth system models (Oertel et al., 2016; Quéré et al., 2018). 
https://doi.org/10.5194/bg-2022-37

Preprint. Discussion started: 8 February 2022

(c) Author(s) 2022. CC BY 4.0 License.

(c) (i)

Here we present new data from an eastern Afrotropical elevational transect, set up in the Kibale Forest and the Rwenzori

Mountains in western Uganda. To gain better insight into the drivers of soil organic C (SOC) respiration, in function of elevation and enhanced warming, we investigated: (i) soil physicochemical properties and the microbial community compositions based on phospholipid fatty acid analysis (PLFA), (ii) heterotrophic soil $\mathrm{CO}_{2}$ respiration rate from laboratory incubations at $60 \%$ water-filled pore space (WFPS) and controlled corresponding in situ temperature, (iii) changes in heterotrophic soil $\mathrm{CO}_{2}$ respiration from intact mesocosm translocated in situ along an elevation gradient to simulate a warming of about $2^{\circ} \mathrm{C}$, (iv) activation energies (AE) and temperature sensitivities $\left(\mathrm{Q}_{10}\right)$ of heterotrophic soil $\mathrm{CO}_{2}$ respiration rates and finally, (v) seasonal total soil $\mathrm{CO}_{2}$ respiration rate under in situ conditions. In particular, we intend to address the following research questions, with respect to a tropical Afromontane elevational transect.

i. Does soil organic matter recalcitrance increase with elevation?

ii. How does soil organic carbon respiration respond to two years of in situ soil warming?

2 Materials and Methods

\subsection{Study area}

The study was conducted in the Kibale Forest National Park and the Rwenzori Mountains National Park in Uganda, both protected by the Uganda Wildlife Authority. A total of twenty sampling plots, each measuring $40 \mathrm{~m}$ by $40 \mathrm{~m}$, were established between 1250 to 3000 meters above sea level (m a.s.l.) along an elevational transect. The sampling plots were grouped into five elevation clusters, with each cluster consisting of four replicated plots within similar elevation and environmental conditions. From the twenty sampling plots, four plots are located in the Kibale Forest National Park at an elevation of 1250-1300 m a.s.l. to form the "premontane" elevation cluster. Sixteen sample plots are located at four different elevation clusters (1750-1850, 2100-2200, 2500-2600 and 2700-3000 m a.s.l.) in the eastern slope of the Rwenzori Mountains National Park (Figure 1).

The Kibale Forest National Park ( $\left.795 \mathrm{~km}^{2} ; 00^{\circ} 30^{\prime} \mathrm{N} 30^{\circ} 24^{\prime} \mathrm{E}\right)$ is located in the Kabarole and Kamwenge districts of western Uganda. The climate is moist tropical, and temperatures stay nearly constant all-year-round. The average annual rainfall is $1365 \pm 53 \mathrm{~mm}$ and the average temperature is $27.8 \pm 0.74{ }^{\circ} \mathrm{C}$ (data 1992-2012, Kyembogo weather station in Kabarole

95 district $20 \mathrm{~km}$ from the park, at elevation of $1400 \mathrm{~m}$ a.s.1., Ministry of Water and Environment). The dominant soil type according to the World Reference Base (WRB) classification is Ferralsol (Jacobs et al., 2016).

The Rwenzori Mountains National Park (998 km²; between $0^{\circ} 06^{\prime} \mathrm{S}-0^{\circ} 46^{\prime} \mathrm{N}$ and $\left.29^{\circ} 47^{\prime} \mathrm{E}-30^{\circ} 11^{\prime} \mathrm{E}\right)$ is located at the border between the Democratic Republic of the Congo (DRC) and Uganda. The region experiences a moist tropical climate, locally affected by altitude and topography. Annual rainfall varies with elevation and slope aspect, with the highest rainfall amounts 
https://doi.org/10.5194/bg-2022-37

Preprint. Discussion started: 8 February 2022

(c) Author(s) 2022. CC BY 4.0 License.

(c) (i)

100 on the eastern slope, where our transect was established. Recent rainfall data from the Uganda Wildlife Authority from 2012 to 2015 showed variations in mean annual rainfall ranging from $7000 \mathrm{~mm}$ at $1760 \mathrm{~m}$ a.s.1. to $1570 \mathrm{~mm}$ at $4230 \mathrm{~m}$ a.s.1.. The mean annual soil temperature of the different elevation clusters is indicated in Figure 1.The dominant soil type in the Rwenzori Mountains according to WRB classification is Leptosol (Jacobs et al., 2016).

\subsection{Soil physicochemical properties and microbial community structure}

In each study plot, the soil temperature at $5 \mathrm{~cm}$ depth was measured daily (during the measurements of soil respiration) at an interval of 30 minutes, using thermocron iButton sensors DS1921G-F5 (iButton, Thermocron Baulkham Hills, Australia). Similarly, the daily volumetric soil moisture content was measured at $5 \mathrm{~cm}$ soil depth using soil moisture sensors (EC-5, Decagon Devices, Armidale, Australia). Further, soil bulk density was determined using the soil core method (Campbell and Henshall, 2000).

At each of the twenty sampling plots along the transect, four topsoil samples $(0-10 \mathrm{~cm})$ of $385 \mathrm{~cm}^{3}$ by volume were collected (i.e. one sample per $20 \mathrm{~m}$ by $20 \mathrm{~m}$ subplot within the 40 by $40 \mathrm{~m}$ sample plot) and homogenised to form one composite sample per plot (4 replicate composite samples per elevation cluster). The samples were oven-dried at $60{ }^{\circ} \mathrm{C}$ and sieved through $2 \mathrm{~mm}$ mesh size and ground. Subsequently, C, nitrogen $(\mathrm{N})$ content and $\delta^{13} \mathrm{C}$ were determined from the composite

115 soil samples using an elemental analyser (automated nitrogen carbon analyser; ANCA-SL, SerCon, Cheshire, U.K.), coupled to an isotope ratios mass spectrometer (IRMS; 20-22, SerCon, Cheshire, U.K.). To measure the soil pH, $5 \mathrm{~mL}$ of the ovendried soil (in triplicate) was brought into suspension with $25 \mathrm{ml}$ of $1 M \mathrm{KCl}(1: 5 \mathrm{v} / \mathrm{v})$ and shaken end-over-end for one hour. Subsequently the suspension was left to settle for two hours, then soil $\mathrm{pH}$ was measured in the supernatant using a pH glass electrode, (model 920A, Orion, England).

For determination of the microbial community structure, about $20 \mathrm{~g}$ of the homogenised composite sample from each plot was frozen immediately after collection. The microbial community structure was determined using phospholipid fatty acid (PLFA) analysis. The PLFA analysis was done by extracting $5 \mathrm{~g}$ of freeze-dried soil sample in duplicate following the method described by Bligh and Dyer (1959), and as modified by Findlay et al. (1989). Briefly, the method involves extraction of all fatty acids, followed by isolation of phospholipids from other soil lipids (using solid-phase extraction), and finally the conversion into fatty acid methyl esters. Accordingly, for each gram of soil sample, lipid extraction was done using a combination of $0.1 \mathrm{M}$ phosphate-buffer, trichloromethane and methanol solvents $(0.9: 1: 2, \mathrm{v} / \mathrm{v})$ at $25^{\circ} \mathrm{C}$. Subsequently, the volume of the total lipid extracts was reduced by evaporating the solvent from tubes under $\mathrm{N}$ gas in a water bath at $30{ }^{\circ} \mathrm{C}$. After, the neutral lipids and glycolipids were eluded using trichloromethane and acetone respectively. Phospholipids were further eluded using methanol and concentrated by evaporation of the solvent under $\mathrm{N}$ gas in a water bath at $30{ }^{\circ} \mathrm{C}$. 
Eventually, the phospholipid fatty acids were converted to methyl esters, which were subsequently analysed using gas chromatography (GC, Trace GC, Thermo Scientific, Bremen, Germany).

\subsection{Laboratory incubations}

To assess soil heterotrophic $\mathrm{CO}_{2}$ respiration rates under controlled laboratory incubations, the homogenised composite 135 samples from each plot were air-dried and sieved ( $2 \mathrm{~mm}$ mesh size) to remove coarse particles and roots. For the incubation experiments, $50 \mathrm{~g}$ of each air-dried composite soil sample from each plot (4 replicates per elevation cluster) was placed in a gas jar of $1 \mathrm{~L}$, which could be closed in an air-tight way by a lid. To each sample, deionised water was added until $60 \%$ WFPS of the respective soil sample (based on total porosity derived from bulk density measurements), representing a moisture content for optimal microbial activity (Aon et al., 2001; Doetterl et al., 2015). The samples were then pre-incubated

140 for 14 days (at the respective in situ mean annual temperature per elevation cluster, i.e. $20,17,15,13$ and $12{ }^{\circ} \mathrm{C}$ for elevation clusters of 1250-1300, 1750-1850, 2100-2200, 2500-2600 and 2700-3000 m a.s.l. respectively). During the pre-incubation, the gas jars were closed with parafilm to permit free air circulation while minimizing the loss of water.

After 14 days of pre-incubation, each sample was removed from the incubator and flushed for 10 seconds with ambient air in

145 the room by means of an air fan. Immediately, one gas sample was taken using a $45 \mathrm{~mL}$ syringe and the ambient $\mathrm{CO}_{2}$ concentrations, and $\delta^{13} \mathrm{C}$ isotopic composition of ambient $\mathrm{CO}_{2}$ at "open conditions" analysed using Cavity Ring-Down Spectrometer, (G2113-I, CRDS $\mathrm{CO}_{2}$ analyser, Picarro, United States) at starting condition. The jars were then closed and placed back in the incubators for 24 hours (a preliminary trial experiment indicated a continuous linear increase in headspace $\mathrm{CO}_{2}$ concentrations during 24 hours). After 24 hours, a $45 \mathrm{~mL}$ gas sample was taken and was immediately introduced into

150 the cavity ring-down spectrometer for measurement of the $\mathrm{CO}_{2}$ concentration and $\delta^{13} \mathrm{C}$ isotopic composition of the respired $\mathrm{CO}_{2}$. After collecting the gas samples under closed conditions, the jars were opened, soil moisture replenished to $60 \%$ WFPS, after which the jars were covered with parafilm and placed back in the incubator until the following measurement (to avoid gas accumulation and to re-establish ambient $\mathrm{CO}_{2}$ concentrations). The following day, the same procedure was repeated, and this was done for five consecutive days to attain five replicated $\mathrm{CO}_{2}$ concentrations that were used to calculate

155 the average respiration rate. To determine the $\delta^{13} \mathrm{C}$ of the respired $\mathrm{CO}_{2}$, we used the Keeling mass balance approach (Keeling, 1958) (equation 1).

$$
\delta^{13} \mathrm{C}-\mathrm{CO}_{2}=\frac{\mathrm{F}^{*} \mathrm{f}-\mathrm{I}^{*} \mathrm{i}}{\mathrm{F}-\mathrm{I}}
$$

Where:

$\mathrm{F}=$ final concentration of $\mathrm{CO}_{2}$ in the headspace;

$160 \mathrm{f}=$ final $\delta^{13} \mathrm{C}$ of $\mathrm{CO}_{2}$ in the headspace;

$\mathrm{I}=$ initial concentration of $\mathrm{CO}_{2}$ in the headspace; 
https://doi.org/10.5194/bg-2022-37

Preprint. Discussion started: 8 February 2022

(c) Author(s) 2022. CC BY 4.0 License.

(c) (i)

$\mathrm{i}=$ initial $\delta^{13} \mathrm{C}$ of $\mathrm{CO}_{2}$ in the headspace.

Subsequently, the isotopic depletion factor, epsilon $(\varepsilon)$, i.e. the extent to which the product of respiration (i.e. $\mathrm{CO}_{2}$ ) becomes depleted in ${ }^{13} \mathrm{C}$ during SOC (substrate) respiration was determined using equation 2.

$$
\varepsilon=\left(\left(\frac{1000+\delta^{13} \mathrm{C}-\mathrm{SOC}}{1000+\delta^{13} \mathrm{C}-\mathrm{CO}_{2}}\right)-1\right) * 1000
$$

Where:

$\varepsilon$ is the isotopic depletion factor

$\delta^{13} \mathrm{C}$-SOC is the $\delta^{13} \mathrm{C}$ of the soil organic carbon

$\delta^{13} \mathrm{C}_{-} \mathrm{CO}_{2}$ is the $\delta^{13} \mathrm{C}$ of the respired $\mathrm{CO}_{2}$

170 The component $\left(\frac{1000+\delta^{13} \mathrm{C}-\mathrm{SOC}}{1000+\delta^{13} \mathrm{C}-\mathrm{CO}_{2}}\right)$ is alpha $(\alpha)$, which is the isotopic fractionation factor.

\subsection{Long-term in situ warming: a soil mesocosm translocation along elevational transect}

In situ climate warming was simulated by translocating intact soil cores $(16 \mathrm{~cm}$ diameter and $25 \mathrm{~cm}$ depth increment) along the altitudinal gradient to the nearest elevation cluster downslope (Figure 1). These intact soil cores were taken using a metallic soil corer in which a plastic PVC tube was inserted to collect an intact soil mesocosm. From each plot, four soil

175 mesocosms were translocated downslope (hereafter referred as "warmed"), while four mesocosms were transplanted within the same plot (hereafter referred as "control"). Each elevation cluster (except the highest) therefore had a total of 16 warmed and 16 control soil mesocosms. The soil mesocosms that were translocated from higher to lower elevation clusters were warmed by about 0.9 to $2.8{ }^{\circ} \mathrm{C}$ on average for two years (Figure 1). 

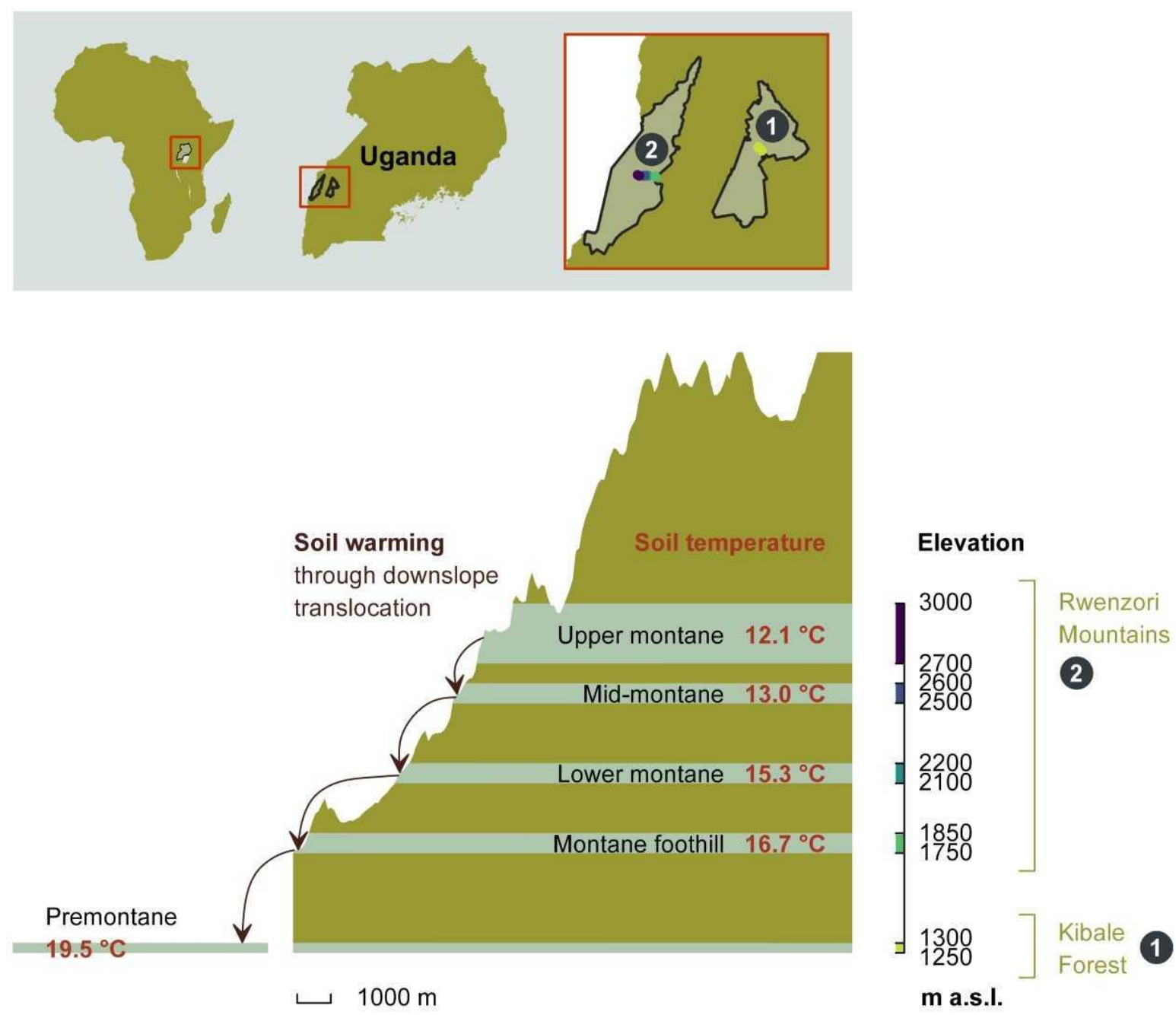

180 Figure 1. The height profile of the Rwenzori elevational transect starting from nearby premontane Kibale Forest National Park (1250-1300 m a.s.l.) onto the Rwenzori Mountains National Park (1750-3000 $\mathrm{m}$ a.s.l.). Mean annual in situ temperatures for each of the five elevation clusters are indicated. The set-up of in situ warming through downslope translocation of soil cores to the immediate lower elevation cluster is illustrated on the left side of the scheme. Different colours on the elevation axis represent the colour code for each elevation cluster throughout the manuscript. 
https://doi.org/10.5194/bg-2022-37

Preprint. Discussion started: 8 February 2022

(c) Author(s) 2022. CC BY 4.0 License.

(c) (i)

After 650 days of in situ incubation between November 2017 to September 2019 of both control and warmed soil cores, the cores were collected. The top $10 \mathrm{~cm}$ of the soil cores was collected (i.e. the soil layer with the highest $\mathrm{C}$ content and most active in C cycling), homogenised, air-dried, and sieved ( $2 \mathrm{~mm}$ mesh size) for additional laboratory incubation experiments, in order to assess the effect of two years of in situ warming on: (i) $\mathrm{CO}_{2}$ respiration rates, (ii) the $\mathrm{AE}$ and $\mathrm{Q}_{10}$ coefficient, (iii) SOC and soil $\delta^{13} \mathrm{C}$ isotopic composition.

To assess the above parameters (i-iii), the soil samples from the translocation experiment were subjected to another incubation experiment under optimal soil moisture conditions. Firstly, the control and warmed samples were incubated at the corresponding mean annual soil temperatures at which they were transplanted in situ (Table 1). Additionally, subsamples from the same soil were also incubated at four other temperatures $\left(5,10,15\right.$ and $30^{\circ} \mathrm{C}$, covering the temperature ranges in the entire elevational transect) to allow determination of $\mathrm{AE}$ and $\mathrm{Q}_{10}$ through curve fitting of the $\mathrm{CO}_{2}$ respiration rates at five different temperatures.

For these experiments, 6-15 g of air-dried soil (where the mass depended on the bulk density) was placed in the gas jar (50 $\mathrm{mL}$ by volume) for each temperature treatment and moistened with deionised water to attain $60 \%$ WFPS. The soil was then gently compressed to a pre-determined height in correspondence with the bulk density of the undisturbed soil. Subsequently, the jars were weighted, covered with parafilm and pre-incubated for 14 days to allow for the re-activation and stabilisation of microbial activities. During the pre-incubation, the soil moisture content in each jar was monitored, and when needed corrected by adding deionised water. After 14 days of pre-incubation, the collection of air samples for the determination of

$205 \mathrm{CO}_{2}$ respiration rate was initiated by removing the parafilm, aerating the samples and closing the lids in an air-tight way. The $\mathrm{CO}_{2}$ concentrations at starting condition and after 24 hours were analysed using a gas chromatograph (Finnigan Trace GC Ultra, Thermo Electron Corporation, Milan, Italy) fitted with a thermal conductivity detector. Eventually, the $\mathrm{CO}_{2}$ respiration rate was determined as the slope of $\mathrm{CO}_{2}$ concentration in function of time.

\subsection{In situ total soil $\mathrm{CO}_{2}$ respiration}

210 Along the Rwenzori elevational transect, we selected one sampling plot in each of the four elevation clusters at 1250-1300, 1750-1850, 2100-2200 and 2700-3000 m a.s.l., for the collection of in situ gas samples. In each study plot, in situ total soil respiration rates were measured following the static chamber method (Collier et al., 2014). Each sampling plot was subdivided into four $20 \mathrm{~m}$ by $20 \mathrm{~m}$ subplots. In each plot, five positions for static chambers were identified, with one position per $20 \mathrm{~m}$ by $20 \mathrm{~m}$ subplot, and another one in the center of the $40 \mathrm{~m}$ by $40 \mathrm{~m}$ permanent sample plot. The collars of

215 the static chambers (to anchor the chamber in the soil) were installed in the soil at least 24 hours before the first gas sampling event and were maintained in the field throughout the sample collection periods to minimise the effect of soil disturbance. Natural litter cover was left intact but plants were not included within the measuring chamber. For respiration rate 
measurements a static, opaque gas chamber was placed on top of the collar, to create a headspace in which $\mathrm{CO}_{2}$ emitted from the soil can accumulate. Both the collars and the chambers are made of polyvinylchloride (PVC) material and were painted white to limit heating of the chamber's headspace air. The chamber was equipped with a vent tube to minimise pressure differences, and a septum connected to a three-way valve to allow the collection of headspace air samples. The headspace volume of the static gas chamber was $5 \mathrm{~L}$ and the surface area was $0.019 \mathrm{~m}^{2}$.

During each sampling event, the five gas chambers were closed for 90 minutes, during which $15 \mathrm{~mL}$ air samples were

collected with a syringe from the chamber headspace at 30-minute intervals starting at time 0 minute until 90 minutes (i.e. $t_{1}$ $=0, t_{2}=30, t_{3}=60$, and $t_{4}=90$ minutes). Prior to air sample collection, the gas chamber headspace was flushed three times with its headspace air using the sampling syringe to homogenise the air in the gas chamber headspace. Headspace air samples of $15 \mathrm{~mL}$ each were immediately injected in $12 \mathrm{~mL}$ pre-evacuated air-tight vials (Labco, Lampeter, Wales, U.K) that were closed with a silicone septum (Dow Corning 734). This created a slight over-pressure in the vials. The headspace air samples were collected for five consecutive days during the start of the rainy season (August 2019), and the same process was repeated in the mid rainy season (September 2019) to account for any seasonal variations in environmental conditions. $\mathrm{CO}_{2}$ emission measurements were not done in the dry season because microbial respiration and temperature sensitivity are low when the WFPS is below $30 \%$ (Aon et al., 2001). The collection of headspace air samples was always consistently executed between 11:00 and 13:00 hours in all plots to minimize the effect of diurnal temperature differences (Keane and Ineson, 2017).

\subsection{Determination of $\mathrm{CO}_{2}$ respiration rates, $\mathrm{AE}$ and $\mathrm{Q}_{10}$}

To convert the measured $\mathrm{CO}_{2}$ concentrations into respiration rates, we fitted a linear regression of the concentrations over time. The derived soil $\mathrm{CO}_{2}$ respiration rates were then expressed in units of grams of $\mathrm{C}$ per unit area per hour (for in situ measurements) or units of grams of $\mathrm{C}$ per unit of soil per hour or normalised per unit SOC (for laboratory incubations) to obtain the "specific" heterotrophic $\mathrm{CO}_{2}$ respiration rate. This was done using the ideal gas law as described in equation (3) to obtain the net gas respiration rates taking into account the headspace volume of the gas chamber, pressure, temperature and molar weight of the gas (Collier et al., 2014; Dalal et al., 2008; Kutzbach et al., 2007).

$$
\mathrm{F}_{\mathrm{C}}=\left[\frac{\Delta \mathrm{C}}{\Delta \mathrm{t}}\right] *\left[\frac{\mathrm{P} * \mathrm{~V}}{\mathrm{R}^{*} \mathrm{~T} * \mathrm{~A}}\right] * \mathrm{M}_{\mathrm{w}}
$$

Where:

$245 \mathrm{~F}_{\mathrm{C}}$ is the resulting gas respiration rate in $\left(\mathrm{g} \mathrm{C} \mathrm{m}^{-2} \mathrm{~h}^{-1}\right)$ (for in situ respiration rates)

$\Delta \mathrm{C}$ is the change in gas concentrations (ppm)

$\Delta \mathrm{t}$ is the change in incubation time (hour)

$\mathrm{P}$ is the pressure (atm) 
https://doi.org/10.5194/bg-2022-37

Preprint. Discussion started: 8 February 2022

(c) Author(s) 2022. CC BY 4.0 License.

(c) (i)

$\mathrm{V}$ is the volume of the gas chamber headspace $(\mathrm{L})$

$250 \mathrm{R}$ is the molar gas constant $\left(\mathrm{L}\right.$ atm $\left.\mathrm{mol}^{-1} \mathrm{~K}^{-1}\right)$

$\mathrm{T}$ is the absolute temperature $(\mathrm{K})$

A is the surface area of the gas chamber $\left(\mathrm{m}^{2}\right)$

$\mathrm{M}_{\mathrm{w}}$ is the molar weight $\left(\mathrm{g} \mathrm{mol}^{-1}\right)$

255 For the laboratory incubation experiments, the parameter A (i.e. the surface area of the gas chamber) was replaced either by the weight of the incubated soil (to express it as " $\mathrm{mg} \mathrm{C} \mathrm{h} \mathrm{hg}^{-1}$ soil" or by the concentration of soil SOC (to express it as " $\mu \mathrm{g}$ $\left.\mathrm{Ch}^{-1} \mathrm{~g}^{-1} \mathrm{SOC}^{\prime \prime}\right)$.

To determine the activation energy of $\mathrm{CO}_{2}$ respiration rate, we employed equation (4) with the respiration rate expressed per 260 unit SOC.

$$
\mathrm{F}_{\mathrm{C}}=\mathrm{b} * \mathrm{e}^{\frac{-\mathrm{AE}}{\mathrm{R} * \mathrm{~T}}}
$$

Where:

$\mathrm{F}_{\mathrm{C}}$ is the specific $\mathrm{CO}_{2}$ respiration rate $\left(\mu \mathrm{g} \mathrm{C} \mathrm{h} \mathrm{g}^{-1} \mathrm{SOC}\right)$

$\mathrm{b}$ is a pre-exponential factor (that is, the theoretical reaction rate constant in the absence of activation energy)

$265 \mathrm{AE}$ is the activation energy in $\mathrm{kJ} \mathrm{mol}^{-1}$

After log transformation, equation (4) becomes:

$$
\ln \mathrm{F}_{\mathrm{C}}=\mathrm{AE} *\left[\frac{-1}{\mathrm{R} * \mathrm{~T}}\right]+\ln \mathrm{b}
$$

Hence, when plotting $\ln \mathrm{F}_{\mathrm{C}}$ against $\frac{-1}{\mathrm{R} * \mathrm{~T}}$, the activation energy can be determined as the slope of the linear regression (SI, 270 Figure 1).

To determine the coefficient for temperature sensitivity of SOC respiration $\left(\mathrm{Q}_{10}\right)$, the $\mathrm{CO}_{2}$ respiration at five different incubation temperatures were firstly fitted to an exponential function, i.e. equation (6) (SI, Figure 2).

$$
\mathrm{F}_{\mathrm{C}}=\mathrm{a} * \mathrm{e}^{\mathrm{k} * \mathrm{~T}}
$$

275 From the two exponential regression constants a and $k$, the $k$ value was used to calculate the $\mathrm{Q}_{10}$, using equation (7).

$$
\mathrm{Q}_{10}=\mathrm{e}^{10 * \mathrm{k}}
$$


https://doi.org/10.5194/bg-2022-37

Preprint. Discussion started: 8 February 2022

(c) Author(s) 2022. CC BY 4.0 License.

(c) (i)

\subsection{Data Analysis}

To determine whether there was a difference in the $\mathrm{CO}_{2}$ respiration rates, $\mathrm{AE}$ and $\mathrm{Q}_{10}$ among the elevation clusters in the

280 elevational transect, we employed analysis of variance (ANOVA) to check differences in means of each variable. Where a significant difference was detected, post-hoc analysis for multiple comparisons was performed using Tukey honest comparison of means to explicitly reveal which elevation clusters differed from each other. We used quantile-quantile and residual plots to check whether the data followed assumptions of ANOVA. To check whether there was a dependency of $\mathrm{CO}_{2}$ respiration rates, $\mathrm{AE}$ and $\mathrm{Q}_{10}$ on elevation, we used the linear mixed effect model regression "Ime4" package in $\mathrm{R}$ 285 software, in which elevation was used as fixed effect and elevation cluster location as random effect (to control for spatial clustering of the sampling plots). To estimate the $P$-values, we used type III analysis of variance with Satterthwaite's approximation method in the linear mixed effect model. In each linear mixed effect model, both marginal $R$ square $\left(\mathrm{R}^{2} \mathrm{~m}\right)$ and conditional $R$ square $\left(R^{2}\right)$ values were obtained following Nakagawa and Schielzeth (2013). Further, to check for a change in $\mathrm{CO}_{2}$ respiration rates, $\mathrm{AE}, \mathrm{Q}_{10}$, SOC content and $\delta^{13} \mathrm{C}$ isotopic composition between control and in situ warmed soil at each elevation cluster, we used a Wilcoxon test. Subsequently, to check the effect of warming along the entire elevational transect, we fitted linear mixed effect model for both control and warmed soil, where elevation was used as fixed effect and the elevation clusters as random. Finally, we employed principal component analysis to explore changes in microbial community and soil physicochemical properties along the elevational transect. All data were analysed using R software (R Core Team, 2021), and a $P$-value of 0.05 was taken as significance level. 
https://doi.org/10.5194/bg-2022-37

Preprint. Discussion started: 8 February 2022

(C) Author(s) 2022. CC BY 4.0 License.

(c) (i)

\section{Results}

\subsection{Physicochemical soil properties and microbial community}

The physicochemical soil properties in the Rwenzori elevational transect are described in 
https://doi.org/10.5194/bg-2022-37

Preprint. Discussion started: 8 February 2022

(C) Author(s) 2022. CC BY 4.0 License.

(c) (i)

Table 1. Along the elevational transect, average annual soil temperature, bulk density and $\mathrm{pH}_{\mathrm{KCl}}$ decreased linearly. On the other hand, SOC, soil total $\mathrm{N}$ and carbon-to-nitrogen $(\mathrm{C}: \mathrm{N})$ ratio, increased linearly with increasing elevation. On the other 300 hand, the $\delta^{13} \mathrm{C}$ of the SOC showed no linear trend along the elevational transect. 
https://doi.org/10.5194/bg-2022-37

Preprint. Discussion started: 8 February 2022

(c) Author(s) 2022. CC BY 4.0 License.

Table 1. Physicochemical soil properties $(0-10 \mathrm{~cm})$ of the elevational transect on the East facing slope of the Rwenzori Mountains National Park (1750-3000 m a.s.l.) and the premontane Kibale Forest National Park (1250-1300 m a.s.l.). Indicated are the mean values plus/minus standard deviations of average annual soil temperature at $5 \mathrm{~cm}$ depth, bulk density $\left(\rho_{\mathrm{b}}\right)$, pH in $\mathrm{KCl}$ solution ( $\mathrm{pH}_{\mathrm{KCl}}$ ), carbon $(\mathrm{C})$ content, nitrogen $(\mathrm{N})$ content, carbon-to-nitrogen ratio $(\mathrm{C}: \mathrm{N})$, and $\delta^{13} \mathrm{C}$. The elevational trend from the linear mixed effect regression model estimate per $100 \mathrm{~m}$ of elevation increase is also indicated with the standard error (SE), $P$-value, marginal $\mathbf{R}^{2}\left(\mathbf{R}^{2} \mathrm{~m}\right)$ and conditional $\mathbf{R}^{2}\left(\mathbf{R}^{2}\right)$.

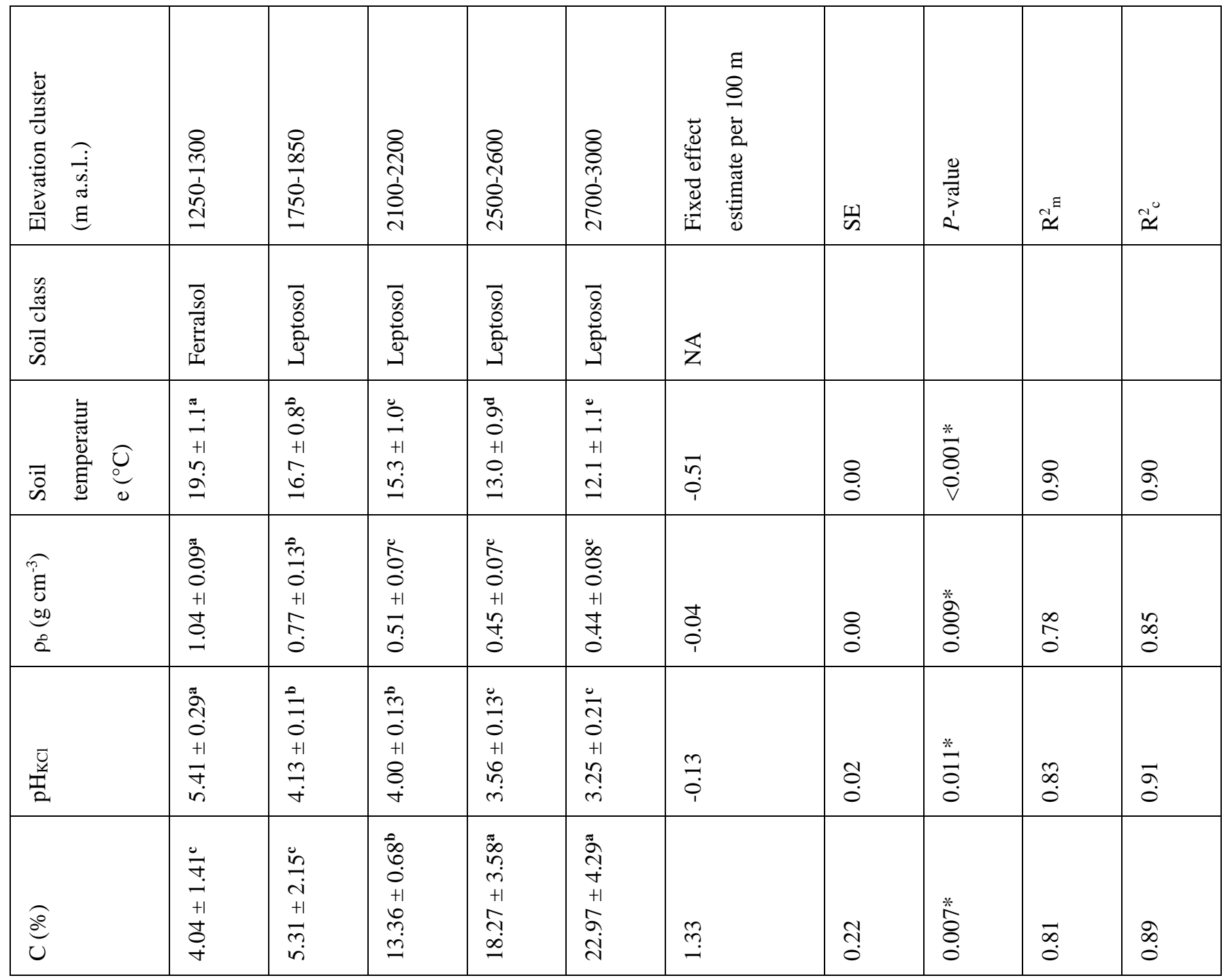


https://doi.org/10.5194/bg-2022-37

Preprint. Discussion started: 8 February 2022

(c) Author(s) 2022. CC BY 4.0 License.

\begin{tabular}{|c|c|c|c|c|c|c|c|c|c|c|}
\hline$\frac{\widehat{d}}{z}$ & $\begin{array}{l}\stackrel{\Xi}{J} \\
\stackrel{0}{0} \\
+1 \\
\dot{J} \\
\dot{0}\end{array}$ & 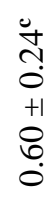 & $\begin{array}{l}\vec{D} \\
\overrightarrow{0} \\
+1 \\
\stackrel{0}{0} \\
\dot{0}\end{array}$ & 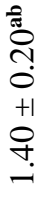 & 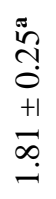 & $\stackrel{8}{0}$ & $\stackrel{-}{\circ}$ & 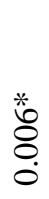 & $\begin{array}{l}\text { CD } \\
0 \\
0\end{array}$ & 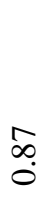 \\
\hline Ü. & $\begin{array}{l}\overrightarrow{0} \\
\dot{0} \\
+1 \\
\vec{a}\end{array}$ & $\begin{array}{l}\hat{n} \\
0 \\
+1 \\
\hat{+} \\
\infty\end{array}$ & $\begin{array}{l}\tilde{\sigma} \\
+1 \\
+1 \\
n \\
\end{array}$ & 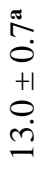 & $\begin{array}{l}a \\
0 \\
0 \\
+1 \\
b \\
\dot{d}\end{array}$ & $\tilde{c}$ & $\stackrel{8}{0}$ & $\begin{array}{l}\stackrel{*}{*} \\
\stackrel{\sigma}{0} \\
\stackrel{0}{*}\end{array}$ & in & $\begin{array}{l}\text { న } \\
0 \\
0\end{array}$ \\
\hline 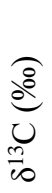 & $\begin{array}{l}\text { है } \\
0 \\
+1 \\
+1 \\
n \\
\\
i\end{array}$ & \begin{tabular}{l}
$\tilde{a}$ \\
0 \\
+1 \\
$n$ \\
\multirow{2}{*}{} \\
1
\end{tabular} & 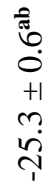 & 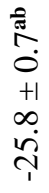 & $\begin{array}{l}\dot{n} \\
0 \\
+1 \\
+ \\
\dot{0} \\
i\end{array}$ & $\begin{array}{l}\stackrel{0}{0} \\
\stackrel{0}{1}\end{array}$ & $\stackrel{?}{0}$ & $\begin{array}{l}n \\
m \\
0\end{array}$ & $\stackrel{m}{\circ}$ & $\tilde{n}$ \\
\hline
\end{tabular}

Different lowercase letters in superscript (bold) next to values of each elevation cluster (same row) indicate a significant difference among the sites at $P<0.05$. The mean values were calculated from 4 separate composite soil samples per elevation cluster and are expressed per unit of dry soil. The $P$-values for a statistically significant elevational linear trends are marked with an asterisk symbol “*”. 
https://doi.org/10.5194/bg-2022-37

Preprint. Discussion started: 8 February 2022

(c) Author(s) 2022. CC BY 4.0 License.

\section{(c) (i)}

Further, at the start of the rainy season, the average in situ soil temperature at $5 \mathrm{~cm}$ depth decreased from $19.6 \pm 0.3{ }^{\circ} \mathrm{C}$ at 1250-1300 m a.s.l. to $11.9 \pm 0.5^{\circ} \mathrm{C}$ at $2700-3000 \mathrm{~m}$ a.s.l. (SI, Table 3). Generally, along the elevational transect, the average soil temperature at the start of the rainy season decreased linearly at a rate of $0.50 \pm 0.04{ }^{\circ} \mathrm{C}$ per $100 \mathrm{~m}$ of elevation increase $\left(\mathrm{R}_{\mathrm{m}}^{2}=0.96, P=0.006\right.$, SI, Figure 3). On the other hand, in the mid rainy season, the average in situ soil temperature decreased from $20.4 \pm 0.4{ }^{\circ} \mathrm{C}$ at $1250-1300 \mathrm{~m}$ a.s.l. to $12.3 \pm 0.4{ }^{\circ} \mathrm{C}$ at $2700-3000 \mathrm{~m}$ a.s.l.. Similarly, in the mid rainy season, the soil temperature decreased linearly by $0.52 \pm 0.06{ }^{\circ} \mathrm{C}$ per $100 \mathrm{~m}$ of elevation increase $\left(\mathrm{R}_{\mathrm{m}}^{2}=0.92, P=0.014\right.$, SI, Figure 3). Additionally, at each elevation cluster, the average soil temperature at $5 \mathrm{~cm}$ depth was significantly higher in the mid rainy season than at the start of the rainy season (SI, Table 3, SI, Figure 3).

In addition, at the start of the rainy season, the average percentage WFPS was 33.1 $\pm 1.2 \%$ at 1250-1300 m a.s.1., $22.2 \pm 2.5$ $\%$ at $1750-1850 \mathrm{~m}$ a.s.1., $41.7 \pm 2.9 \%$ at $2100-2200 \mathrm{~m}$ a.s.1., and $42.7 \pm 8.7 \%$ at 2700-3000 m a.s.1. (SI, Table 3). Generally, along the elevational transect, the average WFPS showed no significant elevational trend at the start of the rainy season (SI, Figure 3). In the mid rainy season, the average percentage water-filled pore space was $57.2 \pm 5.8 \%$ at $1250-1300 \mathrm{~m}$ a.s.l., $44.8 \pm 3.8 \%$ at $1750-1850 \mathrm{~m}$ a.s.1., $45.4 \pm 4.8 \%$ at $2100-2200 \mathrm{~m}$ a.s.l., and finally $44.5 \pm 9.0 \%$ at the highest elevation cluster (2700-3000 $\mathrm{m}$ a.s.1.) (SI, Table 3). Generally, along the elevational transect, the average WFPS showed no significant elevational trend in the mid rainy season (SI, Figure 3). On the other hand, the soil moisture content was always higher in the mid rainy season in all elevation clusters except at 2700-3000 $\mathrm{m}$ a.s.l. (no significant difference) (SI, Table 3).

Finally, along the elevational transect, the microbial community composition showed no significant trend (SI, Figure 4). The percentage of the variability explained by elevation was low for each microbial group, i.e. gram-positive bacteria $\left(\mathrm{R}_{\mathrm{m}}{ }^{2}=\right.$ 0.07), gram negative bacteria $\left(\mathrm{R}_{\mathrm{m}}^{2}=0.01\right)$, fungi $\left(\mathrm{R}_{\mathrm{m}}{ }^{2}=012\right)$, total PLFA (bacteria plus fungi) $\left(\mathrm{R}_{\mathrm{m}}{ }^{2}=0.06\right)$, the ratio of gram-positive to gram-negative bacteria $\left(\mathrm{R}_{\mathrm{m}}^{2}=0.05\right)$ and the ratio of bacteria to fungi $\left(\mathrm{R}_{\mathrm{m}}{ }^{2}=0.10\right)$ (SI, Figure 4). Subsequently, the principle component analysis (PCA) of soil parameters (including microbial community composition), further confirmed that the ratio of bacteria to fungi depicted a weak negative correlation with elevation. Further, the ratio of gram-positive to gram-negative bacteria revealed a weak positive correlation with elevation (Figure 4, SI, Table 2). The parameters of principle component 1 with correlation scores above 0.5 included the total PLFA (bacteria plus fungi), fungi, gram-positive and gram-negative bacteria and physicochemical soil properties (soil bulk density, temperature, $\mathrm{pH}, \mathrm{SOC}$, total N, C:N). On the other hand, parameters of principle component 2 included the total PLFA (bacteria plus fungi), fungi, gram-positive and gram-negative bacteria, and the ratio of gram-positive to gram-negative bacteria and soil $\mathrm{pH}$. Generally, the PCA indeed revealed that the five elevation clusters have similar soil physicochemical properties. Further, it shows that the microbial community vectors are roughly orthogonal to the vectors of soil physicochemical properties. Up to $57.0 \%$ and $23.3 \%$ of the variability in the parameters were explained by principle component 1 and 2 , respectively (Figure 2 , SI, Table 2). 

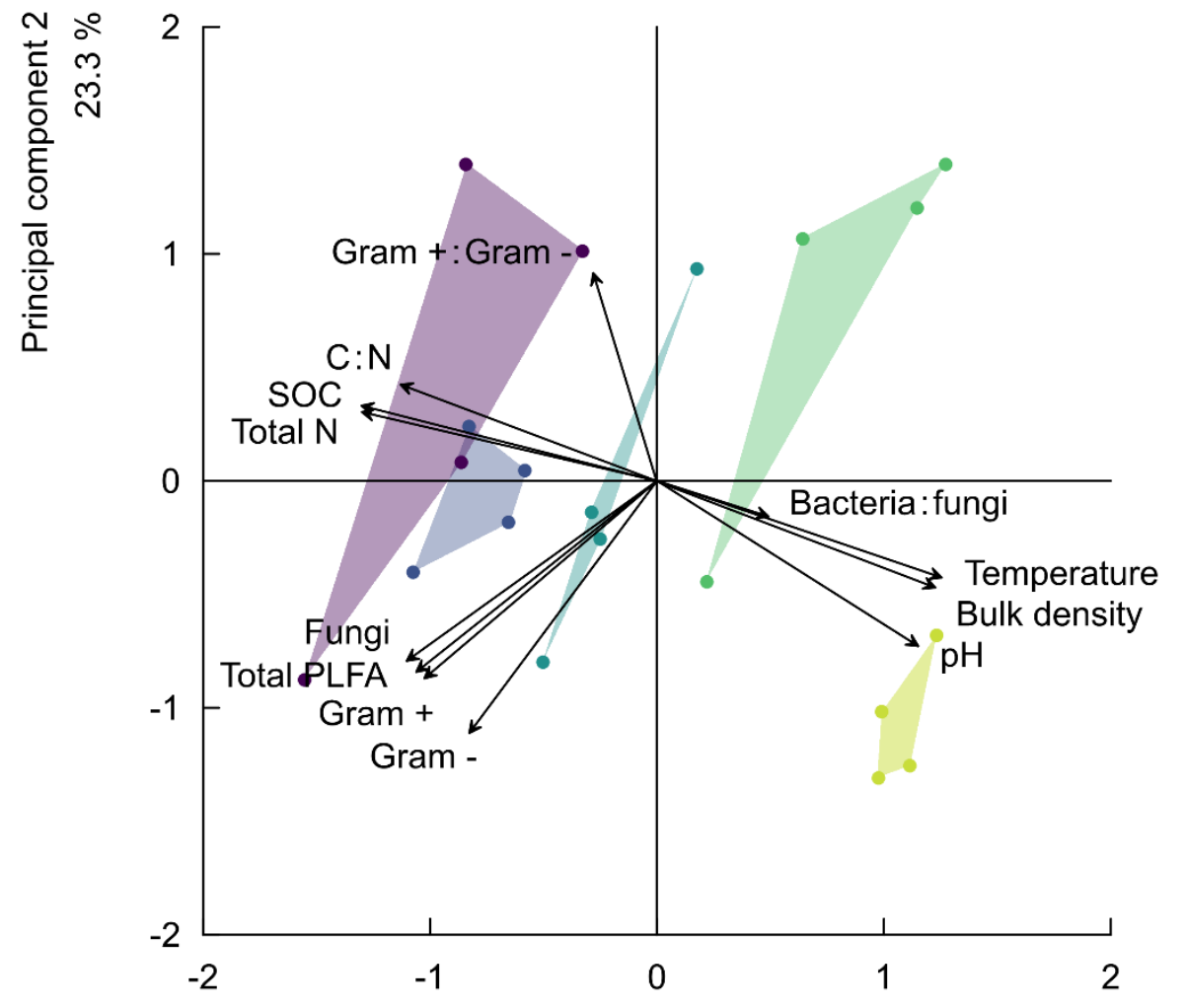

Elevation ( $m$ a.s.I.)

$2700-3000$

$2500-2600$

$2100-2200$

$1750-1850$

$1250-1300$

Principal component 1

$57.0 \%$

345 Figure 2. Principal component analysis (rescaled) of the relationships along elevational transect for soil physicochemical properties (i.e. the soil total nitrogen (total N), soil organic carbon (SOC), carbon-to-nitrogen ratio (C:N), soil pH (pH), soil temperature at 5 cm depth (temperature), bulk density) and the microbial community compositions (i.e. the bacteria to fungi ratio (bacteria:fungi) (total PLFA, in nmol $\mathrm{g}^{-1}$ soil), the ratio of gram-positive-to-gram-negative bacteria (gram+:gram-). The principal component 1 explained $57.0 \%$ of the variability in studied parameters, while principal component 2 explained $23.3 \%$ of the variability. The symbols of the individual plots on the biplot of the first two principal components are shown in different colours per elevation cluster. 
https://doi.org/10.5194/bg-2022-37

Preprint. Discussion started: 8 February 2022

(c) Author(s) 2022. CC BY 4.0 License.

\section{(c) (i)}

\subsection{Laboratory-based heterotrophic soil $\mathrm{CO}_{2}$ respiration rate, $\mathrm{AE}$ and $\mathrm{Q}_{10}$}

The heterotrophic $\mathrm{CO}_{2}$ respiration rates from laboratory incubations at corresponding mean in situ temperature only showed a significant difference when comparing elevation cluster at 2100-2200 m a.s.l. $\left(\mathrm{CO}_{2}\right.$ respiration rate of $0.71 \pm 0.27 \mathrm{mg} \mathrm{Ch}^{-1}$ $\left.\mathrm{kg}^{-1}\right)$ with the elevation cluster at 2700-3000 m a.s.l. $\left(\mathrm{CO}_{2}\right.$ respiration rate of $\left.0.55 \pm 0.15 \mathrm{mg} \mathrm{C} \mathrm{h}^{-1} \mathrm{~kg}^{-1}\right)(P=0.025$, SI, Table 3). Furthermore, the heterotrophic $\mathrm{CO}_{2}$ respiration rate at elevation cluster of $1750-1850 \mathrm{~m}$ a.s.l. was $0.51 \pm 0.20 \mathrm{mg} \mathrm{C} \mathrm{h}^{-1} \mathrm{~kg}^{-}$ ${ }^{1}$ soil, which was statistically similar to the respiration rate of $0.55 \pm 0.15 \mathrm{mg} \mathrm{Ch}^{-1} \mathrm{~kg}^{-1}$ soil at the highest elevation cluster (2700-3000 m a.s.1.). Similarly, heterotrophic respiration rate of $0.67 \pm 0.22 \mathrm{mg} \mathrm{C} \mathrm{h}^{-1} \mathrm{~kg}^{-1}$ soil and of $0.64 \pm 0.25 \mathrm{mg} \mathrm{C} \mathrm{h}^{-1}$ $\mathrm{kg}^{-1}$ soil were recorded for the lowest elevation cluster (1250-1300 m a.s.l.) and the mid-elevation cluster at 2500-2600 m a.s.l., respectively (SI, Table 3). Consequently, heterotrophic $\mathrm{CO}_{2}$ respiration rate from laboratory incubations showed a nonsignificant linear decrease at a rate of $0.004 \pm 0.008 \mathrm{mg} \mathrm{C} \mathrm{h}^{-1} \mathrm{~kg}^{-1}$ per $100 \mathrm{~m}$ of elevation increase $\left(\mathrm{R}_{\mathrm{m}}^{2}=0.007, P=0.677\right.$, Table 2, Figure 3(a)).

In contrast, the specific heterotrophic $\mathrm{CO}_{2}$ respiration rate (normalised per gram of SOC) revealed a significant linear trend along the elevational transect. The highest $\mathrm{CO}_{2}$ respiration rate of $17.2 \pm 5.3 \mu \mathrm{g} \mathrm{C} \mathrm{h}^{-1} \mathrm{~g}^{-1} \mathrm{SOC}$ was detected at the lowest elevation cluster (1250-1300 m a.s.1.). This decreased to $10.8 \pm 4.8 \mu \mathrm{g} \mathrm{C} \mathrm{h}^{-1} \mathrm{~g}^{-1} \mathrm{SOC}$ at $1750-1850 \mathrm{~m}$ a.s.1. and to $5.3 \pm 2.1$ $\mu \mathrm{g} \mathrm{C} \mathrm{h} \mathrm{g}^{-1} \mathrm{SOC}$ at 2100-2200 m a.s.1. Furthermore, lower values of $3.7 \pm 1.9 \mu \mathrm{g} \mathrm{C} \mathrm{h}^{-1} \mathrm{~g}^{-1} \mathrm{SOC}$ and $2.4 \pm 0.9 \mu \mathrm{g} \mathrm{C} \mathrm{h}^{-1} \mathrm{~g}^{-1}$ SOC were observed at the highest two elevation clusters of 2500-2600 m a.s.l. and 2700-3000 m a.s.l., respectively (SI, Table 3). Generally, along the elevation transect, the specific heterotrophic $\mathrm{CO}_{2}$ respiration rate decreased linearly by $1.01 \pm$ $0.12 \mu \mathrm{g} \mathrm{C} \mathrm{h}^{-1} \mathrm{~g}^{-1}$ SOC per $100 \mathrm{~m}$ of elevation increase $\left(\mathrm{R}_{\mathrm{m}}^{2}=0.68, P=0.003\right.$, Table 2, Figure 3(b)).

Further, following the decreasing trend in the specific heterotrophic $\mathrm{CO}_{2}$ respiration rate along the elevational transect, respired $\mathrm{CO}_{2}$ indeed was more depleted in ${ }^{13} \mathrm{C}$ in warmer, lower elevations as compared to colder, higher elevations (Figure 3c). The ${ }^{13} \mathrm{C}$ depletion factor of the respired $\delta^{13} \mathrm{CO}_{2}$ relative to $\delta^{13} \mathrm{C}$-SOC was $3.2 \pm 0.6 \%$ at $1250-1300 \mathrm{~m}$ a.s.1., $2.8 \pm 0.9 \%$ at $1750-1850 \mathrm{~m}$ a.s.1., $1.7 \pm 0.7 \%$ at $2100-2200 \mathrm{~m}$ a.s.1., $1.0 \pm 1.3 \%$ at $2500-2600 \mathrm{~m}$ a.s.1. and $-0.3 \pm 0.8 \%$ at $2700-3000 \mathrm{~m}$

375 a.s.l. (Figure 3(c), SI, Table 3). Along the elevational transect, the ${ }^{13} \mathrm{C}$ depletion factor of the respired $\mathrm{CO}_{2}$ showed a significant linear decrease by $0.23 \pm 0.04 \%$ per $100 \mathrm{~m}$ of elevation increase $\left(\mathrm{R}_{\mathrm{m}}^{2}=0.65, P=0.011\right.$, Table 2 , Figure $\left.3(\mathrm{c})\right)$.

On the other hand, along the elevational transect, $\mathrm{AE}$ ranged from $28.5 \pm 5.6 \mathrm{~kJ} \mathrm{~mol}^{-1}$ in the premontane elevation cluster (1250-1300 m a.s.l.) to $70.3 \pm 6.9 \mathrm{~kJ} \mathrm{~mol}^{-1}$ at $2500-2700 \mathrm{~m}$ a.s.l. and $69.9 \pm 3.0 \mathrm{~kJ} \mathrm{~mol}^{-1}$ in the highest elevation cluster

(2700-3000 m a.s.1.) (SI, Table 3). Generally, along the elevational transect, the AE showed a significant linear increase of $3.2 \pm 0.7 \mathrm{~kJ} \mathrm{~mol}^{-1}$ per $100 \mathrm{~m}$ of elevation increase $\left(\mathrm{R}_{\mathrm{m}}^{2}=3.2, P<001\right)$. Similarly, along the elevational transect, $\mathrm{Q}_{10}$ values ranged from $1.50 \pm 0.13$ in the lowest elevation (1250-1300 m a.s.l.) to $2.68 \pm 0.25$ in the highest elevation (2700-3000 $\mathrm{m}$ a.s.l), (SI, Table 3). Generally, along the elevational transect, the $\mathrm{Q}_{10}$ showed a linear increase of $0.09 \pm 0.03$ per $100 \mathrm{~m}$ of elevation increase $(P=0.012$, Table 2, Figure 3(d)). 

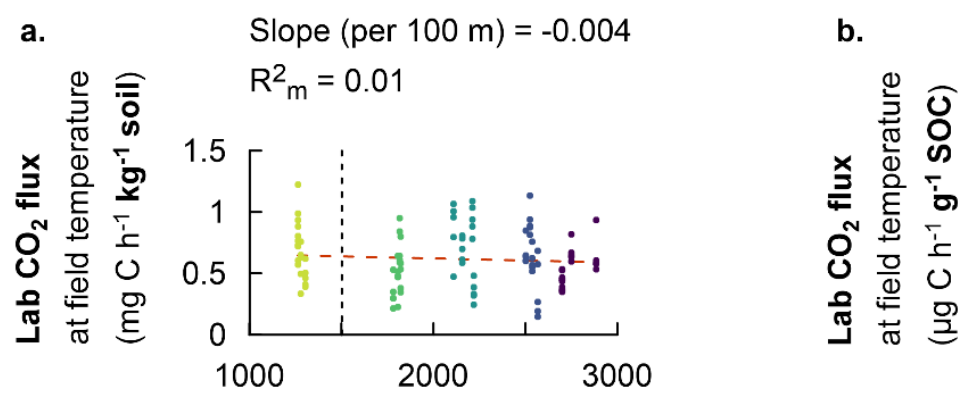

Slope $($ per $100 \mathrm{~m})=-1.01$
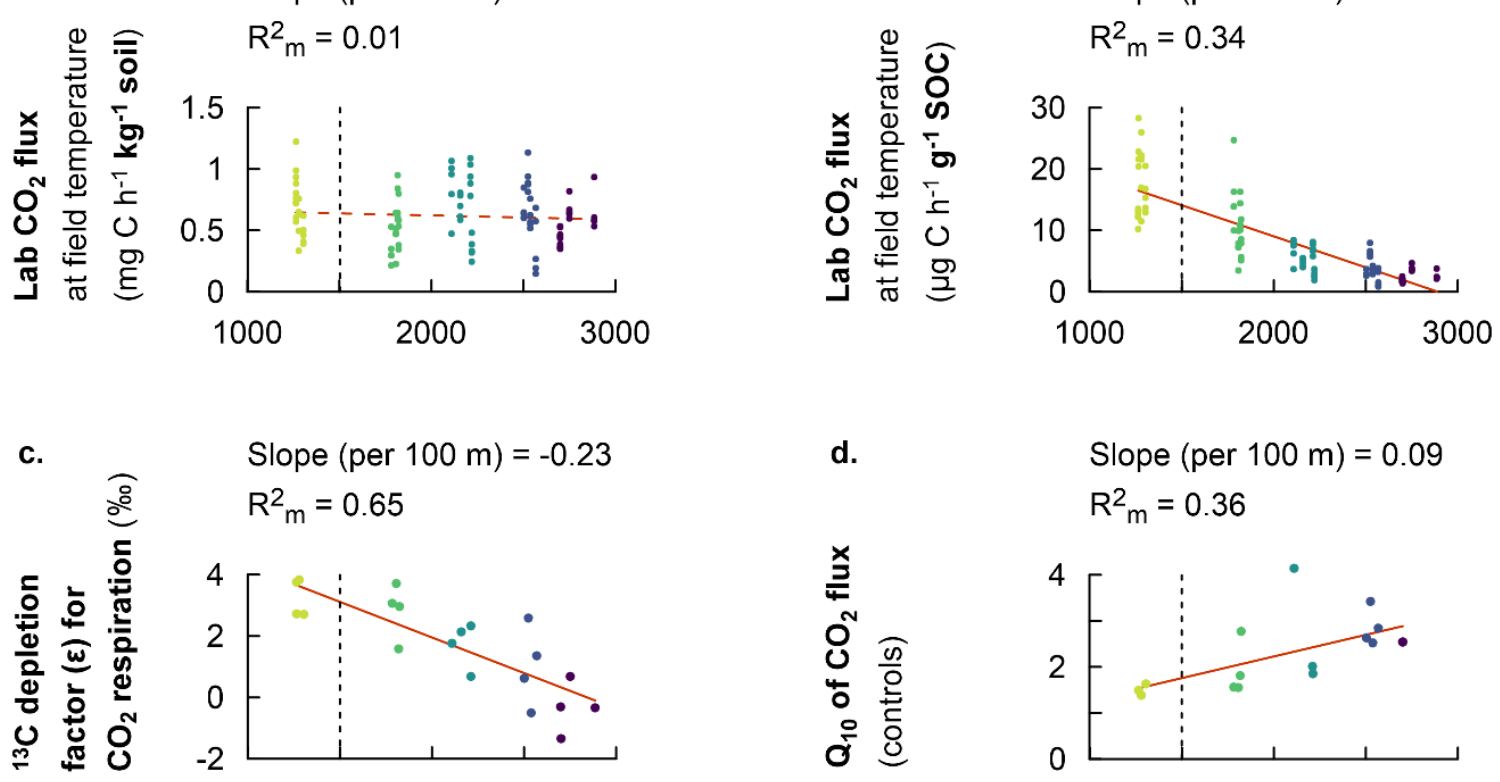

$$
\text { Slope }(\text { per } 100 \mathrm{~m})=-0.23
$$

d.

$$
\begin{aligned}
& \text { Slope }(\text { per } 100 \mathrm{~m})=0.09 \\
& \mathrm{R}_{\mathrm{m}}^{2}=0.36
\end{aligned}
$$
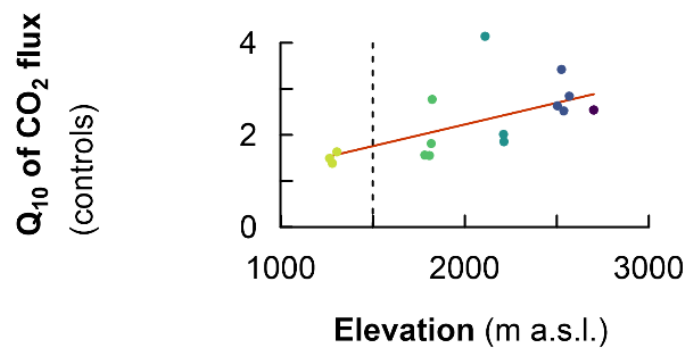

Figure 3. Fixed effect estimates of elevation (per $100 \mathrm{~m}$ elevation increase) on response parameters: laboratory-based heterotrophic $\mathrm{CO}_{2}$ respiration rates at corresponding mean in situ temperature (a), and the specific heterotrophic $\mathrm{CO}_{2}$ respiration rates at corresponding mean in situ temperature (b), the ${ }^{13} \mathrm{C}$ depletion factor for heterotrophic $\mathrm{CO}_{2}$ respiration (c), and the temperature sensitivity of heterotrophic $\mathrm{CO}_{2}$ respiration rates $\left(\mathrm{Q}_{10}\right)(\mathrm{d})$. The slope of the linear mixed effect model estimates per $100 \mathrm{~m}$ of elevation increase is indicated (red solid line for a significant effect and red dashed line for no significant effect), as well as the marginal $R^{2}\left(R^{2}\right.$ ), representing the fraction of the response variable explained by elevation. Plots from montane forest clusters (from 1750-3000 m a.s.l.) were compared with a nearby premontane forest (separated by vertical dashed line) at an elevation of 1250-1300 m a.s.l. 
https://doi.org/10.5194/bg-2022-37

Preprint. Discussion started: 8 February 2022

(c) Author(s) 2022. CC BY 4.0 License.

(c) (i)

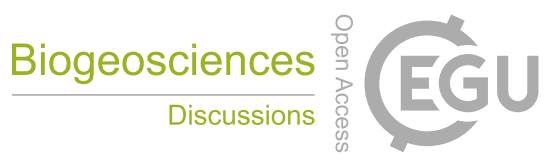

\subsection{Effect of soil warming on $\mathrm{CO}_{2}$ respiration, $\mathrm{AE}, \mathrm{Q}_{10}, \mathrm{SOC}$ and $\delta^{13} \mathrm{C}$}

395 After about 2 years of in situ soil warming, heterotrophic $\mathrm{CO}_{2}$ respiration rates, $\mathrm{AE}$ and $\mathrm{Q}_{10}$ were assessed in a laboratory incubation experiment for control and warmed soil. Additionally, the SOC content and its $\delta^{13} \mathrm{C}$ for control and warmed soil were analysed. The results revealed that at each elevation cluster, there was no significant difference in the studied parameter between control and warmed soil (SI, Table 3). However, along the entire elevational transect, both the non-specific and specific heterotrophic $\mathrm{CO}_{2}$ respiration rates for controlled soil were relatively higher than those of warmed soil (Figure 4a 400 and b respectively, SI, Table 3). Similarly, along the elevational transect, both the $\mathrm{AE}$ and $\mathrm{Q}_{10}$ coefficients for control were relatively higher than those of warmed soil (Figure $4 \mathrm{c}$ and d respectively). Additionally, after two years of in situ soil warming, the SOC contents of warmed soil were relatively lower than those of control along the elevational transect (Figure $4(\mathrm{e})$ ). Finally, the $\delta^{13} \mathrm{C}$ composition of the SOC showed that warmed soil became relatively more enriched in ${ }^{13} \mathrm{C}$ compared to control soil (Figure 4(f)). 
a.

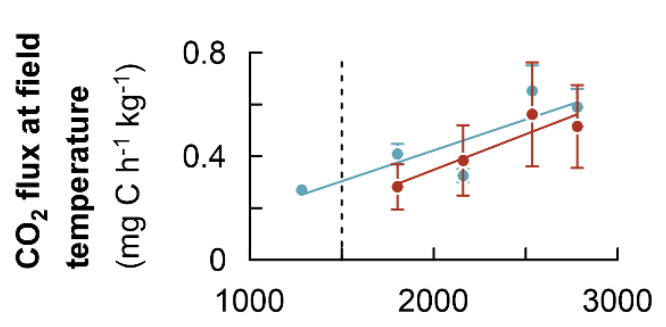

c.

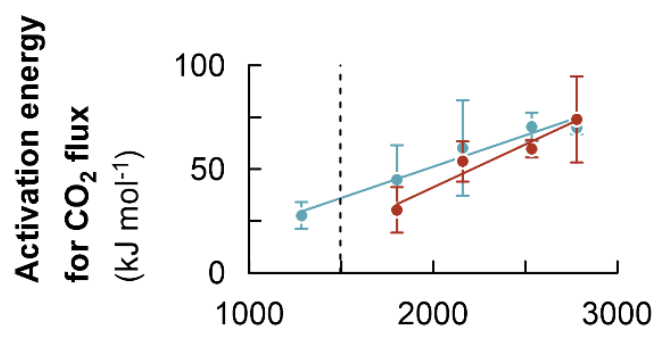

e.

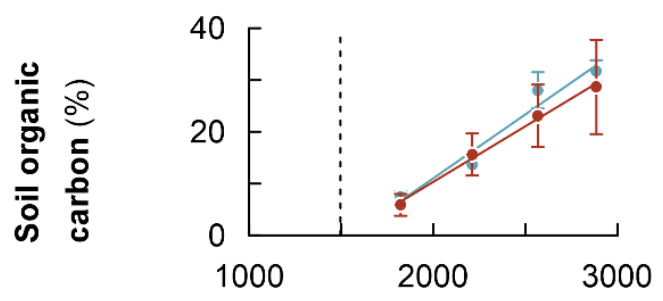

b.

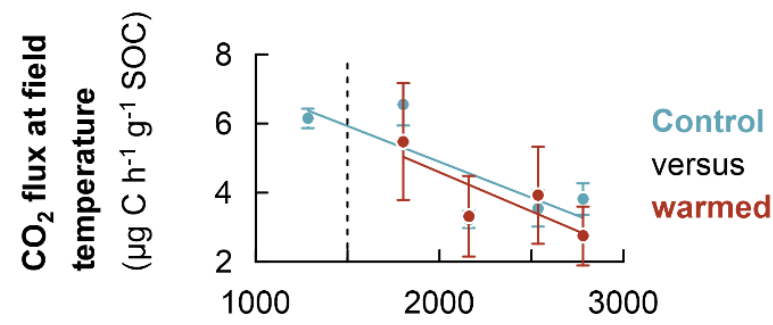

d.

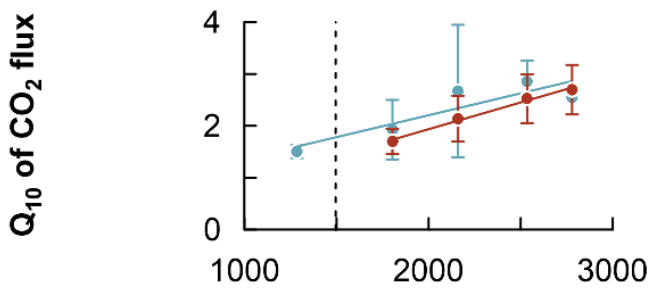

f.

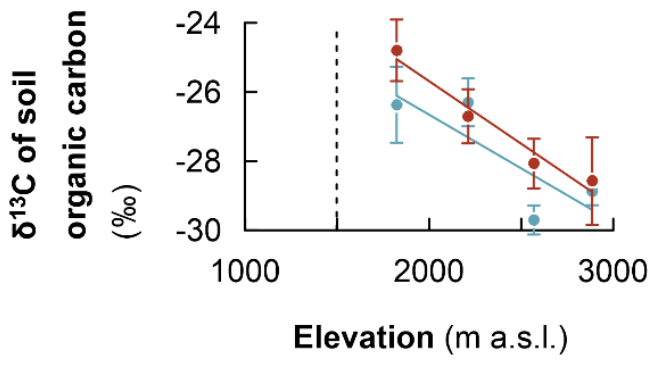

Figure 4. Comparison of warming response of soil organic carbon along the Rwenzori elevational transect; heterotrophic $\mathrm{CO}_{2}$ respiration rates of control and warmed soils (measured at the translocated in situ temperature) (a), idem for the specific $\mathrm{CO}_{2}$ respiration rates (b), activation energy for control and warmed soil (c), sensitivity of $\mathrm{CO}_{2}$ respiration rates to temperature $\left(\mathrm{Q}_{10}\right)$ for control and warmed (d), soil organic carbon content for control and warmed soil (e), and $\delta^{13} \mathbf{C}$ composition of soil organic carbon for control and warmed soil (f). 
https://doi.org/10.5194/bg-2022-37

Preprint. Discussion started: 8 February 2022

(c) Author(s) 2022. CC BY 4.0 License.

(c) (i)

\subsection{In situ $\mathrm{CO}_{2}$ respiration under current conditions at start and mid rainy season}

The in situ total (heterotrophic and autotrophic) $\mathrm{CO}_{2}$ respiration rates along the elevational transect at the start of the rainy season were only significantly different when comparing the upper montane cluster (2700-3000 m a.s.l.) with the rest of the 415 elevation clusters (1250-2200 m a.s.1.) $\left(P=0.027\right.$, SI, Table 3). Total $\mathrm{CO}_{2}$ respiration rate ranged from $95.1 \pm 34.6 \mathrm{mg} \mathrm{C} \mathrm{m}^{-2}$ $\mathrm{h}^{-1}$ in the lower montane elevation at 2100-2200 m a.s.1. to $59.3 \pm 16.7 \mathrm{mg} \mathrm{C} \mathrm{m}^{-2} \mathrm{~h}^{-1}$ at 2700-3000 $\mathrm{m}$ a.s.l.. The total $\mathrm{CO}_{2}$ respiration rate in the lower three elevations (1250-2200 m a.s.l.) were similar, ranging between $79.2 \pm 17.3 \mathrm{mg} \mathrm{C} \mathrm{m}^{-2} \mathrm{~h}^{-1}$ to $95.1 \pm 34.6 \mathrm{mg} \mathrm{C} \mathrm{m}^{-2} \mathrm{~h}^{-1}$ (SI, Table 3). Generally, along the elevational transect, there was no significant linear trend in the total $\mathrm{CO}_{2}$ respiration rate, though this tended to decrease at a rate of $1.04 \pm 1.49 \mathrm{mg} \mathrm{C} \mathrm{m}^{-2} \mathrm{~h}^{-1}$ per $100 \mathrm{~m}$ of elevation increase at the start of rainy season $\left(\mathrm{R}_{\mathrm{m}}^{2}=0.04, P=0.558\right.$, Table 2 , SI, Figure 3$)$.

On the other hand, in the mid rainy season, there was a much stronger variability in the in situ total $\mathrm{CO}_{2}$ respiration rates among the elevation clusters $\left(P<0.001\right.$, SI, Table 3). The total $\mathrm{CO}_{2}$ respiration rate was highest (i.e. $113.2 \pm 35.7 \mathrm{mg} \mathrm{C} \mathrm{m}^{-2}$ $\mathrm{h}^{-1}$ ) in the premontane elevation cluster at $1250-1300 \mathrm{~m}$ a.s.1.. A statistically similar respiration rate of $112.8 \pm 20.3 \mathrm{mg} \mathrm{C} \mathrm{m}^{-2}$

$425 \mathrm{~h}^{-1}$ was found in the montane foothill at $1750-1850 \mathrm{~m}$ a.s.1. There was a significantly lower total $\mathrm{CO}_{2}$ respiration rate (i.e. $89.0 \pm 22.3 \mathrm{mg} \mathrm{C} \mathrm{m}^{-2} \mathrm{~h}^{-1}$ ) at 2100-2200 m a.s.1., which further decreased to $67.7 \pm 9.6 \mathrm{mg} \mathrm{C} \mathrm{m}^{-2} \mathrm{~h}^{-1}$ at 2700-3000 m a.s.1. (SI, Table 3). Overall, along the elevational transect, there was also no significant linear trend in the total $\mathrm{CO}_{2}$ respiration rate which tended to decrease at a rate of $3.25 \pm 0.89 \mathrm{mg} \mathrm{C} \mathrm{m}^{-2} \mathrm{~h}^{-1}$ per $100 \mathrm{~m}$ of elevation increase $\left(\mathrm{R}_{\mathrm{m}}^{2}=0.33, P=0.067\right.$, Table 2, SI, Figure 3).

430

Comparison of seasonal in situ total $\mathrm{CO}_{2}$ respiration rates generally revealed that higher soil moisture contents were associated with higher $\mathrm{CO}_{2}$ respiration rates. Specifically, at 1250-1300 m a.s.l., total $\mathrm{CO}_{2}$ respiration rate at the start of the rainy season $\left(80.1 \pm 15.8 \mathrm{mg} \mathrm{C} \mathrm{m}^{-2} \mathrm{~h}^{-1}\right)$ increased significantly to $113.2 \pm 9.6 \mathrm{mg} \mathrm{C} \mathrm{m}^{-2} \mathrm{~h}^{-1}$ in the mid rainy season $(P<$ 0.001, SI, Table 3). Similarly, the total $\mathrm{CO}_{2}$ respiration rate at $1750-1850 \mathrm{~m}$ a.s.l. increased significantly from $79.2 \pm 17.3$ $\mathrm{mg} \mathrm{C} \mathrm{m}{ }^{-2} \mathrm{~h}^{-1}$ at the start of the rainy season to $112.8 \pm 20.3 \mathrm{mg} \mathrm{C} \mathrm{m}^{-2} \mathrm{~h}^{-1}$ in the mid rainy season $(P<0.001)$. There was no seasonal variation in the total $\mathrm{CO}_{2}$ respiration rate at 2100-2200 $\mathrm{m}$ a.s.l., where the total $\mathrm{CO}_{2}$ respiration rate was between $95.1 \pm 34.6 \mathrm{mg} \mathrm{C} \mathrm{m}^{-2} \mathrm{~h}^{-1}$ and $89.0 \pm 22.3 \mathrm{mg} \mathrm{C} \mathrm{m}^{-2} \mathrm{~h}^{-1}$ in the start and the mid rainy season, respectively. At 2700-3000 $\mathrm{m}$ a.s.l., the total $\mathrm{CO}_{2}$ respiration rate increased significantly from $59.3 \pm 16.7 \mathrm{mg} \mathrm{C} \mathrm{m}^{-2} \mathrm{~h}^{-1}$ in the start of rainy season to $67.7 \pm$ $9.6 \mathrm{mg} \mathrm{C} \mathrm{m}^{-2} \mathrm{~h}^{-1}$ in the mid rainy season $(P=0.035$, SI, Table 3$)$. 
https://doi.org/10.5194/bg-2022-37

Preprint. Discussion started: 8 February 2022

(c) Author(s) 2022. CC BY 4.0 License.

(c) (1)

Table 2. Fixed effect estimates of elevation (per $100 \mathrm{~m}$ elevation increase) on heterotrophic $\mathrm{CO}_{2}$ respiration rates under laboratory incubations at corresponding mean in situ temperature, laboratory-based heterotrophic specific $\mathrm{CO}_{2}$ respiration (normalised per unit soil organic carbon (SOC)), ${ }^{13} \mathrm{C}$ depletion factor for $\mathrm{CO}_{2}$ respiration ( $(\varepsilon)$, and temperature sensitivity of $\mathrm{CO}_{2}$ respiration rate (Q10) for control and warmed soil, and in situ total $\mathrm{CO}_{2}$ respiration rates at the start and in the mid rainy season along the 445 elevational transect. The associated standard error (SE), $\boldsymbol{P}$-value, marginal coefficient of determination ( $\left.\mathbf{R}^{2} \mathrm{~m}\right)$ and conditional coefficient of determination $\left(\mathbf{R}^{2}\right)$ are indicated.

\begin{tabular}{|c|c|c|c|c|c|}
\hline Parameters & Effect estimate & SE & $P$-value & $\mathrm{R}_{\mathrm{m}}^{2}$ & $\mathrm{R}_{\mathrm{c}}^{2}$ \\
\hline $\begin{array}{l}\text { Laboratory-based } \mathrm{CO}_{2} \text { respiration } \\
\left(\mu \mathrm{g} \mathrm{CO}_{2}-\mathrm{C} \mathrm{h}^{-1} \mathrm{~kg}^{-1} \text { soil }\right)\end{array}$ & -0.00 & 0.01 & 0.680 & 0.01 & 0.12 \\
\hline Laboratory-based specific $\mathrm{CO}_{2}$ respiration $\left(\mathrm{mg} \mathrm{CO}_{2}-\mathrm{C} \mathrm{h}^{-1} \mathrm{~g}^{-1} \mathrm{SOC}\right)$ & -1.01 & 0.12 & 0.003* & 0.68 & 0.72 \\
\hline${ }^{13} \mathrm{C}$ depletion factor for $\mathrm{CO}_{2}$ respiration $(\varepsilon)(\%)$ & -0.23 & 0.04 & $0.011 *$ & 0.65 & 0.66 \\
\hline Q10 control & 0.09 & $\mathbf{0 . 0 3}$ & $0.012 *$ & 0.36 & 0.36 \\
\hline Q10 warmed & 0.09 & $\mathbf{0 . 0 3}$ & $0.013 *$ & 0.37 & 0.37 \\
\hline $\begin{array}{l}\mathrm{CO}_{2} \text { respiration at start of rainy season } \\
\left(\mathrm{mg} \mathrm{CO}_{2}-\mathrm{C} \mathrm{h}^{-1} \mathrm{~m}^{-2}\right)\end{array}$ & -1.04 & 1.49 & 0.558 & 0.04 & 0.35 \\
\hline $\begin{array}{l}\mathrm{CO}_{2} \text { respiration in mid rainy season } \\
\left(\mathrm{mg} \mathrm{CO}_{2}-\mathrm{C} \mathrm{h}^{-1} \mathrm{~m}^{-2}\right)\end{array}$ & -3.25 & 0.89 & 0.067 & 0.33 & 0.40 \\
\hline
\end{tabular}

A statistically significant elevational linear trend is bolded and $P$-value marked with asterisk symbol “*”, $\mathrm{R}^{2}{ }_{\mathrm{m}}$ is the proportion of the variance in the response variable explained by the fixed effect (elevation), $\mathrm{R}_{\mathrm{c}}{ }_{\mathrm{c}}$ is the proportion of the variance in the response variable explained by the fixed effect plus random location effects. 
https://doi.org/10.5194/bg-2022-37

Preprint. Discussion started: 8 February 2022

(c) Author(s) 2022. CC BY 4.0 License.

(c) (i)

\section{Discussion}

\subsection{Elevational trend in $\mathrm{CO}_{2}$ respiration, $\mathrm{Q}_{10}$ and ${ }^{13} \mathrm{C}$ depletion factor (Epsilon)}

The specific heterotrophic $\mathrm{CO}_{2}$ respiration decreased along elevation in part, due to negative effect of low temperature on microbial activity (Zimmermann et al., 2009). In support of the temperature effect on $\mathrm{CO}_{2}$ respiration (Figure 3(b)), the ${ }^{13} \mathrm{C}$ fractionation factor for heterotrophic $\mathrm{CO}_{2}$ respiration was also temperature-dependent, such that the respired $\mathrm{CO}_{2}$ at the warm, lower elevations showed a higher fractionation, and subsequently became relatively more depleted in ${ }^{13} \mathrm{C}$ than at the cold, higher elevations (Figure 3(c)). This also indicates that the higher the specific heterotrophic respiration rates, the higher the discrimination against the heavier ${ }^{13} \mathrm{C}$ isotope (Andrews et al., 2000; Natelhoffer and Fry, 1988). These results imply that at higher elevations, even though SOC contents were high, microbial SOC decomposition was limited by low temperatures (Zimmermann et al., 2009). In addition, low $\mathrm{CO}_{2}$ respiration at high elevations is explained by the inhibitory effect of the low soil pH on microbial respiration (Figure 3(c), SI, Table 1) (Rousk et al., 2009), by impairing microbial activity (Walse et al., 1998). Further, the low pH also facilitates the stabilisation of organic matter through complexation reactions with iron and aluminum ions, which become soluble at a low pH (Lützow et al., 2006).

465 Additionally, the observed linear increases in $\mathrm{Q}_{10}$ and $\mathrm{AE}$ with elevation (Table 2, Figure 3(d)), indicate an increasing trend in soil organic matter recalcitrance resulting in lower $\mathrm{CO}_{2}$ respiration at high elevations (Davidson and Janssens, 2006). This is corroborated by the decreasing ${ }^{13} \mathrm{C}$ fractionation (Table 2, Figure 3(c)), as well as lower specific heterotrophic $\mathrm{CO}_{2}$ respiration in higher elevations at a uniform temperature and $60 \%$ WFPS ( $r=-0.53, P=0.02$, SI, Table 2 , SI, Figure 5). The linearly increasing elevational trend in $\mathrm{AE}$ and $\mathrm{Q}_{10}$ is consistent with the intrinsic principles of microbial respiration kinetics

470 associated with the Arrhenius equation (Craine et al., 2010; Davidson and Janssens, 2006; Schipper et al., 2014). Accordingly, the sensitivity of microbial decomposition to an increment in temperature should increase with increasing AE and recalcitrance of the substrate (Craine et al., 2010; Luo et al., 2001; Davidson and Janssens, 2006). As such, more complex (i.e. recalcitrant) $\mathrm{C}$ compounds, for which the microbial decomposition requires more $\mathrm{AE}$, facilitates a lower specific heterotrophic $\mathrm{CO}_{2}$ respiration (SI, Figure 5) and a higher $\mathrm{Q}_{10}$ (i.e. their decomposition is enhanced to a higher extent

475 at a certain increase in temperature) than more simple (i.e. labile) C substrates (Craine et al., 2010; Davidson and Janssens, 2006; Nottingham et al., 2019).

\subsection{Effect of in situ warming}

Generally, after two years of in situ warming, $\delta^{13} \mathrm{C}$ of SOC revealed a relative enrichment in ${ }^{13} \mathrm{C}$ isotope in warmed soil as compared to the control (Figure 4(f)). This is due to enhanced mineralisation rates in the warmed soil. Higher mineralisation 480 causes stronger ${ }^{13} \mathrm{C}$ fractionation (Amundson et al., 2003), due to microbial discrimination against ${ }^{13} \mathrm{C}$ during $\mathrm{C}$ transformation processes (Andrews et al., 2000; Natelhoffer and Fry, 1988). These results imply that warming indeed 
https://doi.org/10.5194/bg-2022-37

Preprint. Discussion started: 8 February 2022

(c) Author(s) 2022. CC BY 4.0 License.

(c) (i)

increased mineralisation of SOC in warmed relative to control soil, owing to the increase in microbial activity at higher temperatures in correspondence with the Arrhenius equation (Craine et al., 2010; Mohan, 2019; Nottingham et al., 2020). Indeed along the elevational transect, SOC was relatively lower in warmed as compared to control (Figure 4(e)). Subsequently, the $\mathrm{CO}_{2}$ respiration for warmed soil were relatively lower than in the controls due to the apparent depletion of respiration substrate during the two years of warming. The evidence of accelerated mineralisation of SOC upon warming supports the results of several soil warming studies that reported an increment in $\mathrm{CO}_{2}$ respiration upon warming (Eliasson et al., 2005; Luo et al., 2001; Melillo et al., 2002; Rustad et al., 2001). The increased decomposition following a temperature increase has the ability to inherently change the content and quality of the SOC, if organic inputs cannot replenish SOC loss

490 at the same rate (Craine et al., 2010; Davidson and Janssens, 2006; Luo et al., 2001). Nonetheless, the lack of significant difference in $\mathrm{CO}_{2}$ respiration rates for warmed and control soil at each elevation cluster after two years of warming may also indicate the fact that labile SOC fractions were not depleted after two years at a higher temperature (Crowther et al., 2016; Davidson and Janssens, 2006; Melillo et al., 2017).

On the other hand, along the elevational transect, the $\mathrm{AE}$ and $\mathrm{Q}_{10}$ values of warmed soils were relatively lower than in the control soils (Figure 4(c) and (d) respectively). This trend is expected as the Arrhenius equation predicts that the $\mathrm{Q}_{10}$ of a certain reaction intrinsically decreases with increasing temperature (Craine et al., 2010; Davidson and Janssens, 2006). As such, SOC substrates would become overall less recalcitrant after two years at an elevated temperature. Indeed, while warming increases the mineralisation rate of the most labile $\mathrm{C}$, it also stimulates the decomposition of recalcitrant $\mathrm{C}$ fractions to a relative higher degree than labile fractions because of the higher $\mathrm{Q}_{10}$ of the former (Craine et al., 2010; Davidson and Janssens, 2006). Subsequently, the $\mathrm{AE}$ and $\mathrm{Q}_{10}$ of warmed soils were relatively lower than those of the controls (Davidson and Janssens, 2006; Mohan, 2019; Nottingham et al., 2020). Both the decrease in SOC contents and the relatively enhanced activation of recalcitrant organic matter upon warming undermine the climate mitigation function of the soil (Davidson and Janssens, 2006; Nottingham et al., 2020; Walker et al., 2018).

\subsection{Present-day $\mathrm{CO}_{2}$ respiration along the Rwenzori elevational transect}

Along the Rwenzori Mountains elevational transect, we observed that the in situ total $\mathrm{CO}_{2}$ respiration rates were significantly lower at the highest elevation cluster of the montane forest in both the start and the mid rainy season as compared to premontane forest. On the other hand, by isolating the effect of moisture in a laboratory incubation (at uniform $60 \%$ WFPS and corresponding in situ measured temperatures per elevation cluster), we found similar heterotrophic $\mathrm{CO}_{2}$ respiration along the transect (SI, Table 3, Figure 3(a)), and ultimately we confirmed a significant linearly decreasing trend for the specific heterotrophic $\mathrm{CO}_{2}$ respiration (Figure 3(b)). This indicates that, under in situ condition, low temperatures and low soil moisture contents limited microbial $\mathrm{CO}_{2}$ respiration at high elevations. Indeed low temperatures at high elevations can have a negative effect on decomposer activities (Finzi et al., 2006; Luo et al., 2006). Meanwhile, an adequate soil 
moisture content can boost microbial respiration by facilitating both the diffusion of soluble substrates and the transport of

oxygen (Liu et al., 2006). Generally, the optimal soil moisture content for microbial respiration is reported to be approximately $60 \%$ WFPS (Aon et al., 2001; Doetterl et al., 2015). Subsequently, in the mid rainy season (when the soil WFPS increased) (SI, Table 3), in correspondence, we detected an increase in the total in situ $\mathrm{CO}_{2}$ respiration rate in all elevation clusters, but at higher elevations between 2100-3000 m a.s.l., the increase in $\mathrm{CO}_{2}$ respiration rates were not significant owing to only a small increase in WFPS in the mid rainy season (SI, Table 3).

The microbial community structure indicated that though the variation of the microbial community (in terms of bacteria and fungi), as a function of elevation is rather limited (SI, Figure 4), there is some shift. In particular, higher elevations are relatively more dominated by gram-positive bacteria (Figure 4, SI, Table 2) and by fungi relative to bacteria (SI, Figure 4), which is also further indictor for higher organic matter recalcitrance (Fanin et al., 2019; Lipson et al., 2002). Based on the principal component analysis and linear mixed effect model analysis of microbial structure (Figure 4, SI, Figure 4), the ratio of total bacteria to fungi slightly decreased with increasing elevation, where it is also known that fungi are often relatively more dominant in soils characterised by more complex organic materials (Lipson et al., 2002), as fungi are more specialised in the breakdown of recalcitrant organic matter (Boer et al., 2005; Coleman et al., 2017). Altogether, we showed that microbial $\mathrm{CO}_{2}$ respiration along the elevational transect was limited by an increasing carbon recalcitrance, decreasing soil temperature, moisture content and $\mathrm{pH}$.

\section{Conclusion}

Our results indicated that global warming can lead to enhanced losses of SOC in montane forests due to their increasing temperature sensitivity and SOC content with elevation. Therefore, the high concentrations of SOC at higher elevations of montane forests are particularly at stake, since the climate warming exactly undermines the mitigating effect of low microbial decomposition under; (i) low temperature (ii) high organic matter recalcitrance (due its higher temperature sensitivity). Further, we showed that along the elevational transect, in situ warming indeed led to increased SOC mineralisation and the associated isotopic fractionation resulted in a relative enrichment of ${ }^{13} \mathrm{C}$ isotope in warmed soils as compared to the controls. This is due to stronger discrimination against the ${ }^{13} \mathrm{C}$ isotope owing to faster SOC transformation processes. Ultimately, along the elevational transect, after two years of warming, the SOC in the warmed soils were

540 relatively lower than in the controls, indicating a depleting trend in SOC owing to the increment in mineralisation during the two years at higher temperature. 
https://doi.org/10.5194/bg-2022-37

Preprint. Discussion started: 8 February 2022

(C) Author(s) 2022. CC BY 4.0 License.

(c) (1)

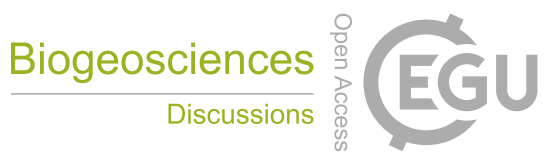

\section{Acknowledgement}

This work was funded by VLIR-OUS and Mountains of the Moon University under the partnership program of Inter-

545 University Cooperation (IUC), grant number UG2019IUC027A103. The authors thank Uganda Wildlife Authority for granting permission to conduct this study in two protected National Parks under permit number UWA/COD/96/05. We also thank staff of the Uganda Wildlife Authority at Rwenzori Mountains and Kibale Forest National Parks for their support. Further, we are grateful to the Research Assistant, Mr. Martin Tuisenge for his tireless efforts and endurance during the demanding field campaigns in the tremendously physically challenging Rwenzori Mountains.

\section{Disclosure statement}

The authors declare that they have no conflict of interest 


\section{References}

Amundson, R., Austin, A. T., Schuur, E. A., Yoo, K., Matzek, V., Kendall, C., Uebersax, A., Brenner, D., and Baisden, W. T.: Global patterns of the isotopic composition of soil and plant nitrogen, Global biogeochemical cycles, 17, https://doi.org/10.1029/2002GB001903, 2003.

Andrews, J. A., Matamala, R., Westover, K. M., and Schlesinger, W. H.: Temperature effects on the diversity of soil heterotrophs and the $\delta 13 \mathrm{C}$ of soil-respired $\mathrm{CO} 2$, Soil Biology and Biochemistry, 32, 699-706, https://doi.org/10.1016/S0038-0717(99)00206-0, 2000.

Aon, M., Sarena, D., Burgos, J., and Cortassa, S.: Interaction between gas exchange rates, physical and microbiological properties in soils recently subjected to agriculture, Soil and Tillage Research, 60, 163-171, https://doi.org/10.1016/S0167-1987(01)00191-X, 2001.

Beer, C., Reichstein, M., Tomelleri, E., Ciais, P., Jung, M., Carvalhais, N., Rödenbeck, C., Arain, M. A., Baldocchi, D., and Bonan, G. B.: Terrestrial gross carbon dioxide uptake: global distribution and covariation with climate, Science, 329, 834-838, https://doi.org/10.1126/science.1184984, 2010.

Bligh, E. G. and Dyer, W. J.: A rapid method of total lipid extraction and purification, Canadian journal of biochemistry and physiology, 37, 911-917, https://doi.org/10.1139/o59-099, 1959.

Boer, W. d., Folman, L. B., Summerbell, R. C., and Boddy, L.: Living in a fungal world: impact of fungi on soil bacterial niche development, FEMS microbiology reviews, 29, 795-811, https://doi.org/10.1016/i.femsre.2004.11.005, 2005.

Campbell, D. J. and Henshall, J. K.: Bulk density, in: Soil and Environmental Analysis, CRC Press, 327-360, 2000.

Carey, J. C., Tang, J., Templer, P. H., Kroeger, K. D., Crowther, T. W., Burton, A. J., Dukes, J. S., Emmett, B., Frey, S. D., and Heskel, M. A.: Temperature response of soil respiration largely unaltered with experimental warming, Proceedings of the National Academy of Sciences, 113, 13797-13802, https://doi.org/10.1073/pnas.1605365113, 2016.

Coleman, D. C., Callaham, M. A., and Crossley Jr, D.: Fundamentals of soil ecology, Academic press2017.

Collier, S. M., Ruark, M. D., Oates, L. G., Jokela, W. E., and Dell, C. J.: Measurement of greenhouse gas flux from agricultural soils using static chambers, Journal of visualized experiments: JoVE,

https://doi.org/10.3791/52110, 2014.

Craine, J. M., Fierer, N., and McLauchlan, K. K.: Widespread coupling between the rate and temperature sensitivity of organic matter decay, Nature Geoscience, 3, 854-857, https://doi.org/10.1038/ngeo1009, 2010.

Crowther, T. W., Todd-Brown, K. E., Rowe, C. W., Wieder, W. R., Carey, J. C., Machmuller, M. B., Snoek, B., Fang, S., Zhou, G., and Allison, S. D.: Quantifying global soil carbon losses in response to warming, Nature, 540, 104-108, https://doi.org/10.1038/nature20150, 2016.

Cuni Sanchez, A., Sullivan, M., Platts, P. J., Lewis, S. L., Marchant, R., Imani, G., Hubau, W., Abiem, I., Adhikari, H., and Albrecht, T.: High aboveground carbon stock of African tropical montane forests, Nature, https://doi.org/10.1038/s41586-021-03728-4, 2021. 
Dalal, R., Allen, D., Livesley, S., and Richards, G.: Magnitude and biophysical regulators of methane emission and consumption in the Australian agricultural, forest, and submerged landscapes: a review, Plant and Soil, 309, 43-76, https://doi.org/10.1007/s11104-007-9446-7, 2008.

Davidson, E. A. and Janssens, I. A.: Temperature sensitivity of soil carbon decomposition and feedbacks to climate change, Nature, 440, 165-173, https://doi.org/10.1038/nature04514, 2006.

Doetterl, S., Stevens, A., Six, J., Merckx, R., Van Oost, K., Pinto, M. C., Casanova-Katny, A., Muñoz, C., Boudin, M., and Venegas, E. Z.: Soil carbon storage controlled by interactions between geochemistry and climate, Nature Geoscience, 8, 780-783, https://doi.org/10.1038/ngeo2516, 2015.

Eliasson, P. E., McMurtrie, R. E., Pepper, D. A., Strömgren, M., Linder, S., and Ågren, G. I.: The response of heterotrophic CO2 flux to soil warming, Global Change Biology, 11, 167-181, https://doi.org/10.1111/j.1365-2486.2004.00878.x, 2005.

Erb, K.-H., Kastner, T., Plutzar, C., Bais, A. L. S., Carvalhais, N., Fetzel, T., Gingrich, S., Haberl, H., Lauk, C., and Niedertscheider, M.: Unexpectedly large impact of forest management and grazing on global vegetation biomass, Nature, 553, 73-76, https://doi.org/10.1038/nature25138, 2018.

Fanin, N., Kardol, P., Farrell, M., Nilsson, M.-C., Gundale, M. J., and Wardle, D. A.: The ratio of Gram-positive to Gram-negative bacterial PLFA markers as an indicator of carbon availability in organic soils, Soil Biology and Biochemistry, 128, 111-114, https://doi.org/10.1016/j.soilbio.2018.10.010, 2019.

Findlay, R. H., King, G. M., and Watling, L.: Efficacy of phospholipid analysis in determining microbial biomass in sediments, Applied and Environmental Microbiology, 55, 2888-2893, https://doi.org/10.1128/aem.55.11.2888-2893.1989, 1989.

615 Finzi, A. C., Moore, D. J., DeLucia, E. H., Lichter, J., Hofmockel, K. S., Jackson, R. B., Kim, H.-S., Matamala, R., McCarthy, H. R., and Oren, R.: Progressive nitrogen limitation of ecosystem processes under elevated $\mathrm{CO} 2$ in a warm-temperate forest, Ecology, 87, 15-25, https://doi.org/10.1890/04-1748, 2006.

Friedlingstein, P., O'sullivan, M., Jones, M. W., Andrew, R. M., Hauck, J., Olsen, A., Peters, G. P., Peters, W., Pongratz, J., and Sitch, S.: Global carbon budget 2020, Earth System Science Data, 12, 3269-3340, https://doi.org/10.5194/essd-12-3269-2020, 2020.

Fussmann, K. E., Schwarzmüller, F., Brose, U., Jousset, A., and Rall, B. C.: Ecological stability in response to warming, Nature Climate Change, 4, 206-210, https://doi.org/10.1038/nclimate2134, 2014.

Gütlein, A., Gerschlauer, F., Kikoti, I., and Kiese, R.: Impacts of climate and land use on N2O and CH 4 fluxes from tropical ecosystems in the Mt. Kilimanjaro region, Tanzania, Global change biology, 24, 1239-1255, https://doi.org/10.1111/gcb.13944, 2018.

IPCC: Global warming of $1.5^{\circ} \mathrm{C}$ : an IPCC special report on the impacts of global warming of $1.5^{\circ} \mathrm{C}$ above pre-industrial levels and related global greenhouse gas emission pathways, in the context of strengthening the global response to the threat of climate change, sustainable development, and efforts to eradicate poverty, Intergovernmental Panel on Climate Change2018. 
IPCC: Summary for Policymakers. In: Climate Change 2021: The Physical Science Basis. Contribution of Working Group I to the Sixth Assessment Report of the Intergovernmental Panel on Climate Change, 2021.

Jacobs, L., Dewitte, O., Poesen, J., Delvaux, D., Thiery, W., and Kervyn, M.: The Rwenzori Mountains, a landslide-prone region?, Landslides, 13, 519-536, https://doi.org/10.1007/s10346-015-0582-5, 2016.

Keane, J. B. and Ineson, P.: Differences in the diurnal pattern of soil respiration under adjacent Miscanthusx giganteus and barley crops reveal potential flaws in accepted sampling strategies, Biogeosciences, 14, 1181-1187, https://doi.org/10.5194/bg-14-1181-2017, 2017.

Keeling, C. D.: The concentration and isotopic abundances of atmospheric carbon dioxide in rural areas, Geochimica et cosmochimica acta, 13, 322-334, https://doi.org/10.1016/0016-7037(58)90033-4, 1958.

Kim, D.-G., Thomas, A. D., Pelster, D., Rosenstock, T. S., and Sanz-Cobena, A.: Greenhouse gas emissions from natural ecosystems and agricultural lands in sub-Saharan Africa: synthesis of available data and suggestions for further research, Biogeosciences, 13, 4789-4809, https://doi.org/10.5194/bg-13-4789-2016, 2016.

Kutzbach, L., Schneider, J., Sachs, T., Giebels, M., Nykänen, H., Shurpali, N., Martikainen, P., Alm, J., and Wilmking, M.: CO 2 flux determination by closed-chamber methods can be seriously biased by inappropriate application of linear regression, Biogeosciences, 4, 1005-1025, https://doi.org/10.5194/bg-4-1005-2007, 2007.

Lewis, S. L., Edwards, D. P., and Galbraith, D.: Increasing human dominance of tropical forests, Science, 349, 827-832, https://doi.org/10.1126/science.aaa9932, 2015.

Lipson, D. A., Schadt, C., and Schmidt, S. K.: Changes in soil microbial community structure and function in an alpine dry meadow following spring snow melt, Microbial ecology, 43, 307-314, https://doi.org/10.1007/s00248-001-1057-x, 2002.

Liu, H. S., Li, L. H., Han, X. G., Huang, J. H., Sun, J. X., and Wang, H. Y.: Respiratory substrate availability plays a crucial role in the response of soil respiration to environmental factors, Applied Soil Ecology, 32, 284-292, https://doi.org/10.1016/j.apsoil.2005.08.001, 2006.

660 Luo, Y., Field, C. B., and Jackson, R. B.: Does Nitrogen Constrain Carbon Cycling, or Does Carbon Input Stimulate Nitrogen Cycling? 1, Ecology, 87, 3-4, 2006.

Luo, Y., Wan, S., Hui, D., and Wallace, L. L.: Acclimatization of soil respiration to warming in a tall grass prairie, Nature, 413, 622-625, https://doi.org/10.1038/35098065, 2001.

Lützow, M. v., Kögel-Knabner, I., Ekschmitt, K., Matzner, E., Guggenberger, G., Marschner, B., and Flessa, H.: Stabilization of organic matter in temperate soils: mechanisms and their relevance under different soil conditions-a review, European journal of soil science, 57, 426-445, https://doi.org/10.1111/j.1365-2389.2006.00809.x, 2006.

Mahmood, R., Pielke Sr, R. A., Hubbard, K. G., Niyogi, D., Dirmeyer, P. A., McAlpine, C., Carleton, A. M., Hale, R., Gameda, S., and Beltrán-Przekurat, A.: Land cover changes and their biogeophysical effects on climate, International journal of climatology, 34, 929-953, https://doi.org/10.1002/joc.3736, 2014. 
Malhi, Y.: The productivity, metabolism and carbon cycle of tropical forest vegetation, Journal of Ecology, 100, 65-75, https://doi.org/10.1111/j.1365-2745.2011.01916.x, 2012.

Melillo, J., Steudler, P., Aber, J., Newkirk, K., Lux, H., Bowles, F., Catricala, C., Magill, A., Ahrens, T., and Morrisseau, S.: Soil warming and carbon-cycle feedbacks to the climate system, Science, 298, 2173-2176, https://doi.org/10.1126/science.1074153, 2002.

Melillo, J. M., Frey, S. D., DeAngelis, K. M., Werner, W. J., Bernard, M. J., Bowles, F. P., Pold, G., Knorr, M. A., and Grandy, A. S.: Long-term pattern and magnitude of soil carbon feedback to the climate system in a warming world, Science, 358, 101-105, https://doi.org/10.1126/science.aan2874, 2017.

Mohan, J. E.: Ecosystem Consequences of Soil Warming: Microbes, Vegetation, Fauna and Soil Biogeochemistry, Academic Press2019.

Nakagawa, S. and Schielzeth, H.: A general and simple method for obtaining R2 from generalized linear mixed-effects models, Methods in ecology and evolution, 4, 133-142, https://doi.org/10.1111/j.2041-210x.2012.00261.x, 2013.

Natelhoffer, K. and Fry, B.: Controls on natural nitrogen-15 and carbon-13 abundances in forest soil organic matter, Soil Science Society of America Journal, 52, 1633-1640, https://doi.org/10.2136/sssaj1988.03615995005200060024x, 1988.

Nottingham, A. T., Meir, P., Velasquez, E., and Turner, B. L.: Soil carbon loss by experimental warming in a tropical forest, Nature, 584, 234-237, https://doi.org/10.1038/s41586-020-2566-4, 2020.

Nottingham, A. T., Whitaker, J., Ostle, N. J., Bardgett, R. D., McNamara, N. P., Fierer, N., Salinas, N., Ccahuana, A. J., Turner, B. L., and Meir, P.: Microbial responses to warming enhance soil carbon loss following translocation across a tropical forest elevation gradient, Ecology letters, 22, 1889-1899, https://doi.org/10.1111/ele.13379, 2019.

Oertel, C., Matschullat, J., Zurba, K., Zimmermann, F., and Erasmi, S.: Greenhouse gas emissions from soils-A review, Geochemistry, 76, 327-352, https://doi.org/10.1016/j.chemer.2016.04.002, 2016.

Pan, Y., Birdsey, R. A., Fang, J., Houghton, R., Kauppi, P. E., Kurz, W. A., Phillips, O. L., Shvidenko, A., Lewis, S. L., and Canadell, J. G.: A large and persistent carbon sink in the world's forests, Science, 333, 988-993, https://doi.org/10.1126/science.1201609, 2011.

Quéré, C., Andrew, R. M., Friedlingstein, P., Sitch, S., Pongratz, J., Manning, A. C., Korsbakken, J. I., Peters, G. P., Canadell, J. G., and Jackson, R. B.: Global carbon budget 2018, Earth Syst. Sci. Data, 10, 405-448, https://doi.org/10.5194/essd-10-2141-2018, 2018.

R Core Team: R: A language and environment for statistical computing (R Version 4.0. 3, R Foundation for Statistical Computing, Vienna, Austria, 2020), 2021.

Rousk, J., Brookes, P. C., and Baath, E.: Contrasting soil pH effects on fungal and bacterial growth suggest functional redundancy in carbon mineralization, Applied and Environmental Microbiology, 75, 1589-1596, https://doi.org/10.1128/AEM.02775-08, 2009.

710 Rustad, L., Campbell, J., Marion, G., Norby, R., Mitchell, M., Hartley, A., Cornelissen, J., and Gurevitch, J.: A meta-analysis of the response of soil respiration, net nitrogen mineralization, 
and aboveground plant growth to experimental ecosystem warming, Oecologia, 126, 543-562, https://doi.org/10.1007/s004420000544, 2001.

Sayer, E. J. and Tanner, E. V.: A new approach to trenching experiments for measuring rootrhizosphere respiration in a lowland tropical forest, Soil Biology and Biochemistry, 42, 347-352, https://doi.org/10.1016/j.soilbio.2009.11.014, 2010.

Sayer, E. J., Heard, M. S., Grant, H. K., Marthews, T. R., and Tanner, E. V.: Soil carbon release enhanced by increased tropical forest litterfall, Nature Climate Change, 1, 304-307, https://doi.org/10.1038/nclimate1190, 2011.

Sayer, E. J., Lopez-Sangil, L., Crawford, J. A., Bréchet, L. M., Birkett, A. J., Baxendale, C., Castro, B., Rodtassana, C., Garnett, M. H., and Weiss, L.: Tropical forest soil carbon stocks do not increase despite 15 years of doubled litter inputs, Scientific reports, 9, 1-9, https://doi.org/10.1038/s41598-019-54487-2, 2019.

Schipper, L. A., Hobbs, J. K., Rutledge, S., and Arcus, V. L.: Thermodynamic theory explains the temperature optima of soil microbial processes and high Q10 values at low temperatures, Global change biology, 20, 3578-3586, https://doi.org/10.1111/gcb.12596, 2014.

Singh, B.: Soil carbon storage: modulators, mechanisms and modeling, Academic Press2018.

Walker, T. W., Kaiser, C., Strasser, F., Herbold, C. W., Leblans, N. I., Woebken, D., Janssens, I. A., Sigurdsson, B. D., and Richter, A.: Microbial temperature sensitivity and biomass change explain soil carbon loss with warming, Nature climate change, 8, 885-889, https://doi.org/10.1038/s41558-018-0259-x, 2018.

Walse, C., Berg, B., and Sverdrup, H.: Review and synthesis of experimental data on organic matter decomposition with respect to the effect of temperature, moisture, and acidity, Environmental Reviews, 6, 25-40, https://doi.org/10.1139/a98-001, 1998.

Zeng, Z., Wang, D., Yang, L., Wu, J., Ziegler, A. D., Liu, M., Ciais, P., Searchinger, T. D., Yang, Z.-L., and Chen, D.: Deforestation-induced warming over tropical mountain regions regulated by elevation, Nature Geoscience, 14, 23-29, https://doi.org/10.1038/s41561-020-00666-0, 2021.

Zhang, W., Parker, K., Luo, Y., Wan, S., Wallace, L., and Hu, S.: Soil microbial responses to experimental warming and clipping in a tallgrass prairie, Global change biology, 11, 266-277, https://doi.org/10.1111/j.1365-2486.2005.00902.x, 2005.

Zimmermann, M., Meir, P., Bird, M. I., Malhi, Y., and Ccahuana, A.: Climate dependence of heterotrophic soil respiration from a soil-translocation experiment along a $3000 \mathrm{~m}$ tropical forest altitudinal gradient, European Journal of Soil Science, 60, 895-906, https://doi.org/10.1111/j.1365-2389.2009.01175.x, 2009. 